\title{
INCONSTITUCIONALIDADE DA DISPENSA ECONÔMICA DE REMESSA NECESSÁRIA DO CPC/2015: INTERESSE PÚBLICO, RAZOABILIDADE E PACTO FEDERATIVO ${ }^{1}$
}

\section{UNCONSTITUTIONALITY OF ECONOMIC EXEMPTIOM OF AUTOMATIC APPEAL OF BRAZILIAN PROCEDURE CODE OF 2015: COLLECTIVE INTEREST, REASONABLENESS AND FEDERALISM}

Caio Gama Mascarenhas Aluno especial do mestrado em Direitos Humanos pela UFMS. Graduado pela Pontifícia Universidade Católica de Goiás e especialista em Direito Constitucional e Administrativo pela mesma instituição. Procurador do Estado do Mato Grosso do Sul. E-mail: caiogm_jus@live.com

RESUMO: Esse trabalho analisa a constitucionalidade das dispensas de remessa necessária do $\S 3^{\circ}$ do artigo 496 do Código de Processo Civil (lei federal n. 13.105/2015), sob o aspecto do interesse público, igualdade material, pacto federativo, autonomia financeira e competências legislativas da União, Estados, Distrito Federal e Municípios. Adicionalmente, faz-se um estudo de proposições legislativas para otimizar a remessa necessária e suas dispensas.

PALAVRAS-CHAVE: Remessa Necessária. Dispensas. $\S^{\circ}$ do artigo 496. Código de Processo Civil. Constitucionalidade.

ABSTRACT: This study analyzes the constitutionality of $\S 3^{\circ}$ of article 496 from Brazilian Procedure Code (Federal law number 13.105/2015), considering rules of collective interest, material equality, federalism, financial autonomy and legislative powers of Federal Government, States, Federal District and municipalities. Additionally, it presents legislative propositions to optimize the automatic appeal and its exemptions.

\footnotetext{
${ }^{1}$ Artigo recebido em 13/06/2017 e aprovado em 16/10/2017.
} 
KEYWORDS: Automatic appeal. Exemptions. $\$ 3^{\circ}$ of article 496. CPC/2015. Constitutionality.

\section{INTRODUÇÃO}

Esse trabalho analisa a constitucionalidade das dispensas de remessa necessária do $\S 3^{\circ}$ do artigo 496 do Código de Processo Civil de 2015 (lei federal n ${ }^{\circ} 13.105 / 2015$ ), sob o aspecto do interesse público, da igualdade material, do pacto federativo, da autonomia financeira e das competências legislativas da União, Estados, Distrito Federal e Municípios.

Inicialmente, examina-se o reexame necessário sob os aspectos dos princípios da indisponibilidade e supremacia do interesse público. Faz-se, outrossim, um estudo sobre a compatibilidade da remessa necessária com a Constituição Federal, enfatizando o papel do Erário como instrumento de efetivação de direitos fundamentais.

Após tal exposição, são apresentados os casos de dispensa de reexame necessário no Código de Processo Civil de 2015, distinguindo-os entre fundamentos de natureza jurisprudencial, administrativa e econômica.

Em relação ao fundamento jurisprudencial de dispensa de reexame necessário, primou-se pela uniformização e otimização dos entendimentos pacificados dos Tribunais Superiores. Na seara da dispensa administrativa de duplo grau de jurisdição obrigatório, observam-se os entendimentos administrativos vinculantes de cada ente federativo.

No tocante aos critérios econômicos de dispensa, entretanto, sobressaiu um aumento expressivo dos limites previstos na lei: revogou-se o limite único de 60 salários mínimos para a instituição de 1.000 salários mínimos para os entes de direito público federal; 500 salários mínimos para os entes de direito público estadual e Municípios que constituam capitais dos Estados e 100 salários mínimos para os demais entes de direito público municipal.

Apresentam-se então os problemas: a razoabilidade, proporcionalidade e efetividade do $\S 3^{\circ}$ do artigo 496 e a legitimidade de uma norma processual, elaborada exclusivamente pelo legislador federal, ter efeitos financeiros sobre Estados, Distrito Federal e Municípios. 
Rio de Janeiro. Ano 12. Volume 19. Número 3. Setembro a Dezembro de 2018

Periódico Quadrimestral da Pós-Graduação Stricto Sensu em Direito Processual da UERJ

Patrono: José Carlos Barbosa Moreira (in mem.). ISSN 1982-7636. pp. 138-171

www.redp.uerj.br

Passa-se então à análise do $§ 3^{\circ}$ do artigo 496 do Código Processual sob o aspecto do respeito ao pacto federativo e às circunstâncias. São diferenciadas as normas processuais das normas meramente procedimentais para fins de delineamento das competências legislativas fixadas na Constituição Federal. Pondera-se ainda sobre a competência legislativa dos Municípios para suplementarem normas federais e estaduais. Analisa-se a visão do Supremo acerca das competências legislativas estaduais, distritais e municipais.

Apresenta-se, ao final, uma proposta: a possibilidade de Estados, Distrito Federal e Municípios legislarem sobre seus limites de reexame necessário com base em suas peculiaridades locais.

\section{REMESSA NECESSÁRIA COMO FORMA DE TUTELA DO ERÁRIO}

O instituto da remessa necessária recebe fortes críticas doutrinárias desde a primeira metade do século passado. Alfredo Buzaid, mentor do Código de Processo Civil de 1973, era contrário ao instituto do reexame necessário previsto no Código de 1939. Na obra "Da apelação ex officio no sistema do Código de Processo Civil", publicada em 1951, o saudoso Ministro do Supremo defendia a extinção de tal prerrogativa da Fazenda Pública ${ }^{2}$.

Os argumentos contrários ao reexame necessário geralmente se baseiam nos princípios da paridade de armas e da isonomia processual. Elpídio Donizzetti ${ }^{3}$ vindica que a advocacia pública encontra-se bem estruturada e com condições para recorrer de todas as decisões opostas aos interesses da Fazenda Pública. Nesse contexto, defende que a remessa necessária seria algo fora de propósito, sobretudo em face da morosidade processual que acomete o direito brasileiro.

Há quem defenda que a distinção utilizada pelo legislador não se justifica, porquanto feriria aos princípios do acesso à justiça e da razoável duração do processo. Defendem, inclusive, o poder disciplinar do Estado que, por ato administrativo (portaria, instrução normativa, ordem de serviço), poderia determinar a seus procuradores o dever de recorrer em determinados casos, sob pena de falta administrativa. Outros aspectos

\footnotetext{
${ }^{2}$ DONIZETTI, Elpídio. Curso Didático de Direito Processual. 19a . ed. São Paulo: Gen, 2016, p. 651.

${ }^{3}$ Ibid., p. 651.
} 
Rio de Janeiro. Ano 12. Volume 19. Número 3. Setembro a Dezembro de 2018

Periódico Quadrimestral da Pós-Graduação Stricto Sensu em Direito Processual da UERJ

Patrono: José Carlos Barbosa Moreira (in mem.). ISSN 1982-7636. pp. 138-171

www.redp.uerj.br

negativos do reexame também são abordados: induziria o advogado público a não recorrer; aumenta a morosidade na prestação jurisdicional; demonstraria desconfiança do legislador em relação ao Juiz de primeiro grau; acarretaria grande desconfiança do cidadão perante os órgãos públicos e o Poder Judiciário ${ }^{4}$.

Tal corrente doutrinária, entretanto, falhou em tentar demonstrar que o instituto do duplo grau de jurisdição obrigatório em favor da Fazenda Pública seria ilegítimo em nosso ordenamento jurídico.

Inicialmente, destaca-se que a estrutura dos órgãos de advocacia pública é uma questão aferida de forma regionalizada, inclusive no âmbito da União. É equivocado defender que todos os órgãos de advocacia pública da União, Distrito Federal, 26 Estados federados e 5.570 Municípios, estão suficientemente estruturados.

Nota-se que não se trata de aferir se os órgãos de advocacia pública possuem estrutura necessária, se os juízes são diligentes no ofício nem de defender a desídia dos procuradores no exercício de suas funções. O escopo desse instituto é tutelar o Erário de preclusões processuais em primeira instância - momento em que o interesse público discutido em juízo se encontra mais propenso às casualidades e às subjetividades das partes, procuradores e órgãos judiciais.

Em relação à punibilidade dos advogados públicos que deixem, indevidamente, de recorrer de sentenças condenatórias, tal fato não mitiga o dano causado ao Erário. Segundo o art. 184 do Código de Processo Civil de 2015, o advogado público somente será civil e regressivamente responsável quando agir com dolo ou fraude no exercício de suas funções. O Erário, portanto, não poderia cobrar judicialmente os valores de lesão ocorrida nos casos em que não pudesse provar a ocorrência de dano ou fraude - ônus probatório extremamente dificultoso na prática.

Um dos fundamentos do reexame necessário é o fato de que fenômeno da litigância de massa é verificado com bastante frequência em demandas propostas contra a Fazenda Pública. A Fazenda Pública é, portanto, um litigante habitual ${ }^{5}$.

A essência da remessa necessária se apresenta de forma externa ao Processo Civil, na medida em que busca preservar determinados valores muito significativos, como os

\footnotetext{
${ }^{4}$ BORELLI, Rafael de Souza; SOARES, Marcos Antônio Striquer. Análise crítica do reexame necessário à luz do acesso à justiça e da razoável duração do processo. Revista de Estudos Jurídicos UNESP, Franca, v. 16, n. 24. 2012.

${ }^{5}$ CUNHA, Leonardo Carneiro da. A Fazenda Pública em juízo. 13a edição. Rio de Janeiro: Dialética, 2016, p. 208-209.
} 
Rio de Janeiro. Ano 12. Volume 19. Número 3. Setembro a Dezembro de 2018

Periódico Quadrimestral da Pós-Graduação Stricto Sensu em Direito Processual da UERJ

Patrono: José Carlos Barbosa Moreira (in mem.). ISSN 1982-7636. pp. 138-171

www.redp.uerj.br

interesses públicos defendidos pela Fazenda Pública. Nas demandas contra o Poder

Público, exige-se que decisões que lhes sejam desfavoráveis (embora possivelmente corretas no caso concreto) fossem tomadas não apenas por um único órgão jurisdicional monocrático, mas confirmadas obrigatoriamente também por instância superior ${ }^{6}$ - uma espécie de dupla fiscalização judicial.

Rafael Sérgio de Lima Oliveira pondera que o fundamento do duplo grau de jurisdição obrigatório pode ser cindido em dois: um de ordem jurídica e outro de ordem fática ${ }^{7}$.

O fundamento jurídico é extraído do regime próprio de direito público que rege as relações do Erário - indissociável da noção de interesse público. Todas as atividades legítimas desenvolvidas pelo Estado são em prol da coletividade.

O interesse público (interesse da coletividade) caracteriza o sentido público dos interesses individuais, enquanto bem jurídico de todo um conjunto social. Ainda quando o Poder Público age em vista de algum interesse financeiro estatal, o escopo de sua ação é centrado, impreterivelmente, no interesse público. Faltando esse objetivo, o ato administrativo estará viciado por desvio de finalidade.

$\mathrm{Na}$ seara fática, a remessa necessária se baseia em duas questões: a possibilidade de falha da representação judicial do Poder Público em juízo e a corrupção dos agentes públicos no trato do Erário.

$\mathrm{Na}$ visão de José Carlos Barbosa Moreira, o instituto é indispensável porquanto, embora haja qualidade de atuação dos procuradores do Erário, não se pode eliminar a falibilidade da Advocacia Pública. Conquanto usualmente os procuradores da Fazenda sejam diligentes no exercício de suas funções, não se extingue a possibilidade de que algum deles, por algum motivo, deixe de interpor apelação contra sentença desfavorável. Será hipótese rara, mas não inconcebível. A regra da remessa necessária seria concebida para tais casos ${ }^{8}$.

O instituto da remessa necessária nada mais é que a materialização dos princípios da indisponibilidade do interesse público e supremacia do interesse público sobre o particular na seara processual. Exatamente por defender o interesse público, incumbe à

\footnotetext{
${ }^{6}$ DECOMAIN, 2012, p. 109.

${ }^{7}$ OLIVEIRA, Rafael Sérgio Lima de. O reexame necessário à luz da duração razoável do processo. Curitiba: Juruá, 2011, p. 174.

${ }^{8}$ MOREIRA, José Carlos Barbosa. Em defesa da revisão obrigatória das sentenças contrárias à Fazenda Pública. Revista do Instituto de Pesquisas e Estudos, Bauru, n. 44, p. 79-88, set./dez. 2005, p. 209.
} 
Revista Eletrônica de Direito Processual - REDP.

Rio de Janeiro. Ano 12. Volume 19. Número 3. Setembro a Dezembro de 2018

Periódico Quadrimestral da Pós-Graduação Stricto Sensu em Direito Processual da UERJ

Patrono: José Carlos Barbosa Moreira (in mem.). ISSN 1982-7636. pp. 138-171

www.redp.uerj.br

Fazenda Pública atuar no processo da melhor e mais ampla maneira possível, evitando-se condenações injustificáveis ou prejuízos incalculáveis para o Erário. Agindo assim, toda a coletividade seria beneficiada com a tutela processual de tais verbas públicas ${ }^{9}$.

O Erário configura fundamental instrumento de garantia de direitos - os recursos financeiros do Poder Público são imprescindíveis porquanto proveem os meios para a realização do interesse público primário. Sem as verbas públicas necessárias, o Estado não tem capacidade de promover investimentos sociais nem de executar, de forma adequada, os serviços públicos essenciais para a sociedade ${ }^{10}$. Daí a melhor abordagem para os serviços públicos e os direitos é vê-los como liberdades privadas com custos públicos ${ }^{11}$.

Considerando o Erário como instrumento de efetivação de direitos, deve ser considerada a quantidade de demandas judiciais por prestações sociais positivas em face do Estado. Ressaltam-se as demandas na área da saúde, que cresceram exponencialmente na última década ${ }^{12}$, necessitando de uma atenção melhor dos Tribunais nos casos de alto custo.

Ressalta-se, ainda, que o instituto da remessa necessária já foi declarado constitucional pelo Supremo Tribunal Federal no julgamento da Ação Declaratória Constitucional 4. Tal Ação Declaratória de Constitucionalidade foi ajuizada perante a Suprema Corte com o escopo de garantir a aplicação do art. $1^{\circ}$ da Lei $n^{\circ}$ 9.494/97. Esse dispositivo limita as hipóteses de concessão de tutela antecipada contra a Fazenda Pública. Um de seus itens era referente à possibilidade de atribuição de efeito suspensivo ao

\footnotetext{
${ }^{9}$ CUNHA, Leonardo Carneiro da. A Fazenda Pública em juízo. 11 a edição. Rio de Janeiro: Dialética, 2013, p. 34 .

${ }^{10}$ BARROSO, Luis Roberto. Curso de Direito Constitucional Contemporâneo. $5^{\mathrm{a}}$ ed. São Paulo: Saraiva, 2015, p. 95

${ }^{11}$ NABAIS, José Casalta. A face oculta dos direitos fundamentais: os deveres e os custos dos direitos. Revista Direito Mackenzie, São Paulo, v. 3, n. 2, 2002: "E uma primeira verificação, que devemos desde já assinalar a tal respeito, é esta: os direitos, todos os direitos, porque não são dádiva divina nem frutos da natureza, porque não são auto-realizáveis nem podem ser realisticamente protegidos num estado falido ou incapacitado, implicam a cooperação social e a responsabilidade individual. Daí que a melhor abordagem para os direitos seja vê-los como liberdades privadas com custos públicos. Na verdade, todos os direitos têm custos comunitários, ou seja, custos financeiros públicos. Têm portanto custos públicos não só os modernos direitos sociais, aos quais toda a gente facilmente aponta esses custos, mas também custos públicos os clássicos direitos e liberdades, em relação aos quais, por via de regra, tais custos tendem a ficar na sombra ou mesmo no esquecimento. Por conseguinte, não há direitos de borla, apresentando-se todos eles como bens públicos em sentido estrito".

${ }^{12}$ CONSELHO NACIONAL DE JUSTIÇA. Justiça em números 2016: ano-base 2015/Conselho Nacional de Justiça. O Conselho Nacional de Justiça divulgou, em um de seus relatórios, números sobre a judicialização da saúde, considerando os processos ajuizados até 2015. Se somadas todas as demandas existentes no $1^{\circ}$ grau, no $2^{\circ}$ grau, nos Juizados Especiais, no Superior Tribunal de Justiça, nas Turmas Recursais e nas Turmas Regionais de Uniformização, encontra-se o número de 854.506 ações de saúde. Apenas para registro, em 2011 eram 240.980 processos judiciais. Em 2014, o total era de 392.921.
} 
reexame necessário contra sentença que importe em outorga ou adição de vencimentos ou de reclassificação funcional.

Devido à causa de pedir aberta e ao caráter dúplice e ambivalente das ações diretas de inconstitucionalidade e ações declaratórias de constitucionalidade, nada impediria que o Supremo, na parte referente ao recurso de ofício, julgasse inconstitucional tal prerrogativa da Administração Pública. Preferiu, no entanto, declarar sua constitucionalidade e plena aplicação em nosso ordenamento jurídico.

Tudo isso, aliado aos fatos de que a Fazenda Pública sempre atua em prol do interesse coletivo e de que o Erário é um instrumento para a efetivação dos direitos fundamentais, fundamenta o instituto do reexame necessário em favor do ente público.

\section{DA REMESSA NECESSÁRIA NO CÓDIGO DE PROCESSO CIVIL DE 2015}

De fato, houve inúmeras tentativas de extinguir o instituto da remessa necessária desde o Código de Processo Civil de 1939. Na elaboração do Código de Processo Civil de 2015 , não foi diferente.

Após a instituição da Comissão de Juristas encarregada de elaborar Anteprojeto do Novo Código de Processo Civil (ato no 379, de 2009, do Presidente do Senado Federal), foram elaboradas decisões acerca das proposições temáticas do Novo Código. Tais decisões apontavam as diretrizes que o projeto de lei seguiria em fase anterior à elaboração da redação dos dispositivos. No item "5 - Recursos", destacava-se a alínea "r", que tinha a seguinte proposição: "extinguir a remessa necessária".

Por falta de apoio necessário na elaboração do projeto de Código, não se conseguiu suprimir o instituto da remessa necessária do Diploma Processual, embora tenham sido alteradas substancialmente as hipóteses de dispensa de remessa necessária.

Antes de adentrar no tema das dispensas, é importante lembrar que o reexame necessário pode ser mitigado. A Corte Especial do STJ entendeu que o reexame necessário não é exigência constitucional nem constitui prerrogativa de caráter absoluto em favor da Fazenda, nada impedindo que a lei o dispense, como o faz em várias situações ${ }^{13}$.

As mudanças no duplo grau de jurisdição obrigatório serão expostas a seguir.

\footnotetext{
${ }^{13}$ EREsp 345.752/MG, $1^{\text {a }}$ Seção, DJ 05/12/2005, p. 207.
} 
Rio de Janeiro. Ano 12. Volume 19. Número 3. Setembro a Dezembro de 2018

Periódico Quadrimestral da Pós-Graduação Stricto Sensu em Direito Processual da UERJ

Patrono: José Carlos Barbosa Moreira (in mem.). ISSN 1982-7636. pp. 138-171 www.redp.uerj.br

\subsection{DO RECURSO VOLUNTÁRIO INTERPOSTO E A REMESSA NECESSÁRIA}

A primeira mudança que deve ser destacada é a supressão da concomitância de julgamento entre remessa necessária e recurso voluntário (art. 496, § 1º, CPC/2015).

No Código de Buzaid, o reexame necessário era assegurado com a cláusula expressa "haja ou não apelação" (475, §1º, do CPC/1973) - independia, portanto, de recurso voluntário. Conforme o Novo Código, se a apelação já foi voluntariamente interposta, não há mais a necessidade de o juiz proceder à formalização da remessa oficial.

Humberto Theodoro Júnior vindica que a sistemática do Código anterior complicava o julgamento do tribunal, que tinha de se pronunciar sobre dois incidentes: a remessa necessária e a apelação. Esse fato quase sempre culminava na declaração de ter restado prejudicado o recurso da Fazenda Pública, haja vista a absorção de seu objeto pelo decidido no primeiro expediente ${ }^{14}$.

Uma questão a ser questionada seria o grau de devolutividade do recurso cabível. Nos casos em que cabível a remessa necessária, poderia o Tribunal se manifestar sobre as questões não impugnadas pela apelação do ente público?

A posição mais razoável indica que $\operatorname{sim}^{15}$. Entendimento contrário levaria à conclusão de que seria mais vantajoso à Fazenda Pública não recorrer da sentença, na medida em que sua omissão acarretaria um reexame da matéria mais completo do que a interposição do recurso cabível - indo de encontro ao escopo do próprio instituto da remessa necessária. Embora parcial o recurso da Fazenda Pública, a remessa obrigatória será total ${ }^{16}$.

Por fim, questiona-se o fato de o $\S 1^{\circ}$ do art. 496 ser taxativo em relação à ocorrência de reexame necessário somente no caso de não interposição da apelação no prazo legal. O que aconteceria se, embora interposto tempestivamente pela Fazenda, o recurso fosse inadmitido pelo órgão do Tribunal?

A solução mais lógica seria dar o mesmo tratamento da ausência de recurso, devendo o Tribunal analisar toda a matéria discutida na causa, independente de o recurso

\footnotetext{
14 THEODORO JUNIOR, Humberto. Novo Código de Processo Civil Anotado. 20ª Ed. Rio de Janeiro. Gen, 2016, p. 1.247.

${ }^{15}$ CUNHA, Leonardo Carneiro da. A Fazenda Pública em juízo. 13a edição. Rio de Janeiro: Dialética, 2016., p. 192.

${ }^{16}$ Enunciado no 432 do Fórum Permanente de Processualistas Civis - ENFAM.
} 
Rio de Janeiro. Ano 12. Volume 19. Número 3. Setembro a Dezembro de 2018

Periódico Quadrimestral da Pós-Graduação Stricto Sensu em Direito Processual da UERJ

Patrono: José Carlos Barbosa Moreira (in mem.). ISSN 1982-7636. pp. 138-171

www.redp.uerj.br

inadmitido ter sido interposto. Não pode a Fazenda ter um tratamento pior no caso de recurso inadmitido do que o teria se tivesse se omitido.

\subsection{DISPENSA COM FUNDAMENTO JURISPRUDENCIAL}

Dispensa-se o reexame necessário quando a sentença estiver fundada em: a) súmula de tribunal superior; b) acórdão proferido pelo Supremo Tribunal Federal ou pelo Superior Tribunal de Justiça em julgamento de recursos repetitivos e c) entendimento firmado em incidente de resolução de demandas repetitivas ou de assunção de competência (art. 496, § $4^{\circ}$, I a III, do NCPC).

Essa norma é reflexo de um dos principais objetivos do Código Processual de 2015: estimular a uniformização de jurisprudência no território nacional e fortalecer os precedentes judiciais.

Nesse aspecto, houve um claro aperfeiçoamento do CPC/2015 em relação ao texto do Código revogado, que previa como causas de dispensa apenas a existência de jurisprudência do Plenário do Supremo Tribunal Federal ou súmula de tribunal superior (art. 475, § $3^{\circ}$, do CPC/1973).

Em relação ao julgamento das demandas sob o rito dos recursos repetitivos, notase que há evidente fortalecimento enquanto precedente judicial. Essa atualização foi necessária, porquanto o julgamento de demandas repetitivas é tão relevante quanto a edição de uma súmula de jurisprudência, que está em franco desuso ${ }^{17}$.

Na redação original do CPC/1973, configurava uma medida inócua e contrária ao princípio da celeridade a remessa necessária dos autos para o segundo grau de jurisdição quando o julgado já estivesse fundamentado em tese consolidada pelos tribunais superiores. Provocava acúmulo de trabalho inútil nos tribunais, na medida em que eram obrigados a proferir julgamento acerca de teses jurisprudenciais já consolidadas. Com o escopo de eliminar tal situação, sobreveio a minirreforma no CPC, revogado por meio da Lei federal $n^{\circ} 10.352$.

A dispensa de remessa necessária com fundamento jurisprudencial é fruto dos movimentos da comunidade jurídica pela valorização dos precedentes. O instituto do duplo

\footnotetext{
${ }^{17}$ SCALABRIN, Felipe; SANTANNA, Gustavo. Perfil da remessa necessária no novo código de processo civil. Revista da AJURIS, Porto Alegre, v. 42, n. 137, mar. 2015.
} 
Revista Eletrônica de Direito Processual - REDP.

Rio de Janeiro. Ano 12. Volume 19. Número 3. Setembro a Dezembro de 2018

Periódico Quadrimestral da Pós-Graduação Stricto Sensu em Direito Processual da UERJ

Patrono: José Carlos Barbosa Moreira (in mem.). ISSN 1982-7636. pp. 138-171

www.redp.uerj.br

grau de jurisdição obrigatório sofreu o primeiro reflexo dessa tendência em 2001, com a citada Lei $n^{\circ} 10.352$.

O Novo Código de Processo Civil valorizou, ainda mais, a jurisprudência no processo civil brasileiro, colocando a uniformização jurisprudencial pelos Tribunais Superiores e sua observância pelas instâncias inferiores como um dos maiores objetivos do novo Código ${ }^{18}$.

A tarefa constitucional das Cortes em definir o sentido dos textos constitucionais é primordial para o Estado Democrático de Direito ${ }^{19}$.

Portanto, se a remessa necessária possui seu fundamento no interesse público ${ }^{20}$, também é de interesse público que a Administração Pública siga a interpretação de lei dada pelas Cortes Superiores, porquanto submetida ao princípio da legalidade.

Consolidada determinada interpretação de norma jurídica (por meio de súmula ou julgamento de demandas ou recursos repetitivos), o sentido dado ao interesse público já foi exaustivamente debatido e consolidado nas instâncias judiciárias. Nesses casos, o fundamento material do duplo grau de jurisdição obrigatório já estaria atendido, razão pela qual seria dispensada a remessa ${ }^{21}$.

\subsection{DISPENSA POR ORIENTAÇÃO ADMINISTRATIVA}

A dispensa de defesa ou recurso por orientação administrativa decorre do princípio da autotutela. A Administração Pública, ao cometer erros, pode revê-los para restaurar a situação de regularidade, visto que se submete ao princípio da legalidade. Não

\footnotetext{
${ }^{18}$ Cita-se trecho da exposição de motivos do CPC/2015: "Prestigiou-se, seguindo-se direção já abertamente seguida pelo ordenamento jurídico brasileiro, expressado na criação da súmula vinculante do Supremo Tribunal Federal (STF) e do regime de julgamento conjunto de recursos especiais e extraordinários repetitivos (que foi mantido e aperfeiçoado) tendência a criar estímulos para que a jurisprudência se uniformize, à luz do que venham a decidir tribunais superiores e até de segundo grau, e se estabilize. Essa é a função e a razão de ser dos tribunais superiores: proferir decisões que moldem o ordenamento jurídico, objetivamente considerado. A função paradigmática que devem desempenhar é inerente ao sistema".

${ }^{19}$ CUNHA, Guilherme; REIS, Maurício apud SCALABRIN, Felipe; SANTANNA, Gustavo, op. cit., p. 313 : "Sem qualquer pretensão de exaurimento, vale destacar que, se as Cortes definem o sentido dos textos, é evidente que a autoridade do direito também está nos precedentes, pois a decisão judicial não mais define a exata interpretação da lei (declara a vontade da lei), mas atribui sentido ao direito. A tarefa jurisdicional não está limitada a revelar a lei ou declarar algo que sempre esteve à disposição, mas sim, define o adequado sentido do texto, adicionando algo à ordem jurídica - que passa a ser composta, também, pelo precedente".

${ }^{20}$ MOREIRA, José Carlos Barbosa. Em defesa da revisão obrigatória das sentenças contrárias à Fazenda Pública. Revista do Instituto de Pesquisas e Estudos, Bauru, n. 44, p. 79-88, set./ dez. 2005, p. 209-210.

${ }^{21}$ SCALABRIN, Felipe; SANTANNA, Gustavo, op. cit., p. 315.
} 
Rio de Janeiro. Ano 12. Volume 19. Número 3. Setembro a Dezembro de 2018

Periódico Quadrimestral da Pós-Graduação Stricto Sensu em Direito Processual da UERJ

Patrono: José Carlos Barbosa Moreira (in mem.). ISSN 1982-7636. pp. 138-171

www.redp.uerj.br

se configura apenas uma faculdade, mas também um dever, pois não se pode admitir que, diante de situações irregulares, permaneça a Administração inerte e desinteressada. Ressalta-se que a autotutela envolve dois aspectos quanto à atuação administrativa: a) aspectos de legalidade - situação em que Administração, de ofício, procede à revisão de atos ilegais; e b) aspectos de mérito, situação em que reexamina atos anteriores quanto à conveniência e oportunidade de sua manutenção ou desfazimento ${ }^{22}$.

A Administração Pública pode, dentro desses aspectos, editar norma que a dispense de apresentar defesa. No caso de uma sentença, legitimamente fundamentada, que reconheça que determinado ato administrativo é ilegal, é recomendável - ou até mesmo obrigatório - que a Administração Pública não apresente recurso. Havendo orientação administrativa do órgão administrativo no mesmo sentido da tese jurídica adotada pela sentença, a remessa necessária seria medida inútil e desarrazoada.

Denota-se que já havia previsão de dispensa do reexame necessário por orientação administrativa anteriormente ao Código de 2015. A hipótese abrangia sentença proferida contra a União, suas autarquias e fundações públicas, nos casos em que a AGU ou órgão administrativo competente houvesse editado súmula ou instrução normativa determinando a não interposição de recurso voluntário (art. 12 da Medida Provisória no 2.180-35). A regra, no entanto, atingia apenas a Administração Pública Federal.

Ampliando essa hipótese de dispensa, o Novo Código estabelece que não haverá remessa quando a sentença estiver fundada em "entendimento coincidente com orientação vinculante firmada no âmbito administrativo do próprio ente público, consolidada em manifestação, parecer ou súmula administrativa" (art. 496, § 4º, IV, do CPC/2015). Essa regra é aplicada independentemente de quem seja o ente federativo ou pessoa jurídica de direito público litigante. Cuida-se de mais uma medida que atende ao interesse público.

Ressalta-se que, para se dar efetividade a esse comando do Novo Código, incumbe à Administração Pública dar publicidade às suas orientações vinculantes, preferencialmente pela rede mundial de computadores ${ }^{23}$.

\subsection{DA DISPENSA POR FUNDAMENTO ECONÔMICO}

\footnotetext{
${ }^{22}$ CARVALHO FILHO, José dos Santos. Manual de Direito Administrativo. 30ª ed. São Paulo: Atlas, 2016, p. 88.

${ }^{23}$ Enunciado n ${ }^{\circ} 433$ do Fórum Permanente de Processualistas Civis - ENFAM.
} 
Rio de Janeiro. Ano 12. Volume 19. Número 3. Setembro a Dezembro de 2018

Periódico Quadrimestral da Pós-Graduação Stricto Sensu em Direito Processual da UERJ

Patrono: José Carlos Barbosa Moreira (in mem.). ISSN 1982-7636. pp. 138-171

www.redp.uerj.br

Uma modificação da remessa necessária, contudo, foi bastante controversa: o $\S 3^{\circ}$ do art. 496, referente à dispensa de remessa necessária com fundamento econômico.

O limite para a remessa passou de um valor unitário de 60 (sessenta) saláriosmínimos para: 1.000 (mil) salários-mínimos para a União e as respectivas autarquias e fundações de direito público; 500 (quinhentos) salários-mínimos para os Estados, o Distrito Federal, as respectivas autarquias e fundações de direito público e os Municípios que constituam capitais dos Estados; e 100 (cem) salários-mínimos para todos os demais Municípios e respectivas autarquias e fundações de direito público.

Cuida-se de uma vitável modificação que em nada atende ao interesse público nem ao acesso à justiça, como veremos a seguir.

\section{DO PRINCÍPIO DA RAZOABILIDADE E PROPORCIONALIDADE NAS ESCOLHAS LEGISLATIVAS EM PROCESSO CIVIL}

\subsection{DO PRINCÍPIO DA RAZOABILIDADE E O PODER DE LEGISLAR}

Ser razoável é uma exigência inerente ao exercício de qualquer função pública, inclusive à do legislador. Conforme o Estado Democrático de Direito, a moderação e a racionalidade devem orientar toda e qualquer ação estatal, em todos os Poderes e entes federativos da República.

Na elaboração das leis, o princípio da razoabilidade impõe a obrigação de os legisladores executarem as suas funções com equilíbrio, coerência e bom senso. Não é suficiente atender às regras do processo legislativo. Importa, também, saber como o fim público deve ser atendido pela lei a ser criada. Cuida-se de exigência implícita e indissociável ao devido processo legislativo ${ }^{24}$.

Em razão disso, o Supremo Tribunal Federal, por mais de uma vez, já declarou a inconstitucionalidade de lei por violação ao princípio, tanto de lei federal ${ }^{25}$, quanto de lei

\footnotetext{
${ }^{24}$ CARVALHO FILHO, José dos Santos. Op. cit. p. 95.

${ }^{25}$ ADI 4.467, Rel. Min. Ellen Gracie, em 30.9.2010.
} 
Revista Eletrônica de Direito Processual - REDP.

Rio de Janeiro. Ano 12. Volume 19. Número 3. Setembro a Dezembro de 2018

Periódico Quadrimestral da Pós-Graduação Stricto Sensu em Direito Processual da UERJ

Patrono: José Carlos Barbosa Moreira (in mem.). ISSN 1982-7636. pp. 138-171

www.redp.uerj.br

estadual $^{26}$. Essas declarações da Suprema Corte destacam que esse tipo de ofensa afeta realmente o plano de validade dos atos ${ }^{27}$.

O STF pende para a tese de que o legislador deve observar os princípios da razoabilidade e do interesse público ao elaborar a norma processual.

A Suprema Corte, em alguns julgados ${ }^{28}$, analisou o princípio da razoabilidade nas leis processuais. Em tais ocasiões, o STF fez ponderações sobre o princípio da razoabilidade do legislador em matéria processual, nos casos em que o Poder Público integra o processo. Reconheceu-se como constitucional, portanto, o regime jurídico distinto da Fazenda Pública quando litiga em juízo.

Igualmente, o Supremo já julgou leis inconstitucionais pelo crivo do princípio da proporcionalidade por diversas vezes ${ }^{29}$. Tal princípio é um princípio geral do direito, configurando forte ferramenta de interpretação para todo o ordenamento jurídico. Quaisquer restrições de direitos, concessão de poderes, privilégios ou benefícios devem passar por um controle de legitimidade e equilíbrio.

\footnotetext{
${ }^{26}$ ADI 1.158, Rel. Min. Dias Toffoli, em 08.10.2014.

${ }^{27}$ Ressalta-se que o princípio da razoabilidade possui uma relação intrínseca e histórica com o princípio do devido processo legal, como bem explica o ex-Procurador-Geral da República, Dr. Geraldo Brindeiro, em seu parecer pela constitucionalidade do art. $1^{\circ}$ da Lei $n^{\circ}$ 9.494/97 na ADC 4: "No Direito Constitucional Americano o conceito de razoabilidade (reasonableness) desenvolveu-se paralelamente ao do devido processo legal (due process of law). A moderna teoria constitucional preocupa-se em distinguir o que é razoável, do simplesmente lógico ou racional, distinção percebida há muito pelo Justice HOLMES, visão reconhecida nas teorias dialéticas de RECASENS SICHES e MIGUEL REALE, que procuram dar o necessário conteúdo valorativo às decisões e ao processo jurídico e judicial. A cláusula do devido processo legal, introduzida em 1789 pela 5 a Emenda à Constituição Americana e estendida aos Estados pela 14a Emenda, refere-se, numa primeira fase, apenas a garantias de natureza processual propriamente ditas relativas a orderly proceedings. Segundo sua concepção originária e adjetiva, não visava a questionar a substância ou o conteúdo dos atos do Poder Público mas sim assegurar o direito ' a um processo regular e justo. A partir de 1890, todavia, a Suprema Corte, por meio de construção jurisprudencial (construction) e baseando-se em critérios de razoabilidade (reasonableness), conferiu ao princípio o sentido de proteção substantiva dos direitos e liberdades civis assegurados no Bill of Rights e passou a promover a proteção dos direitos fundamentais contra ação irrazoável e arbitrária (protection from arbitrary and unreasonable action). E, como observou o Justice HARLAN no caso Griswold v. Connecticut, 381, US 479 (1965), o conceito do devido processo legal não pode ser reduzido a uma fórmula ou referência a um código: tem representado o equilíbrio desenvolvido pela jurisprudência da Corte entre os postulados do respeito à liberdade do indivíduo e os imperativos da sociedade organizada ('Due process' has no $t$ been reduced to any formula: its content cannot be determined by reference to any code. The best that can be said is that through the course of this Court's decisions it has represented the balance which our Nation, built upon postulates of respect for the liberty of the individual, has struck between that liberty and the demands of organized society')".

${ }^{28}$ ADC 4 - tutela antecipada, ADI n- 223 e ADI n- 1.576 - tutelas cautelares

${ }^{29}$ ADI 4.425, pub. 19-12-2013; HC 104.410, pub. 27-3-2012; dentre outros
} 
Rio de Janeiro. Ano 12. Volume 19. Número 3. Setembro a Dezembro de 2018

Periódico Quadrimestral da Pós-Graduação Stricto Sensu em Direito Processual da UERJ

Patrono: José Carlos Barbosa Moreira (in mem.). ISSN 1982-7636. pp. 138-171

www.redp.uerj.br

Esse princípio, segundo Karl Larenz ${ }^{30}$, consubstancia uma pauta de natureza axiológica que emana diretamente das ideias de justiça, equidade, bom senso, prudência, moderação, justa medida, proibição de excesso, direito justo e valores afins.

Como parâmetro de interpretação, o princípio da proporcionalidade impõe o preenchimento de três importantes elementos:

1) Necessidade/exigibilidade: nesse contexto, a adoção da medida que possa restringir direitos só se legitima se indispensável para o caso concreto e não se puder substituí-la por outra menos gravosa;

2) Adequação/pertinência/idoneidade: determina-se que o meio escolhido deve atingir o objetivo perquirido; e

3) Proporcionalidade em sentido estrito: a medida necessária e adequada deve avaliar se o ato praticado, em termos de realização do objetivo pretendido, supera a restrição a outros valores constitucionalizados. Há de se ter um custo-benefício na medida, buscando uma máxima efetividade e mínima restrição.

\subsection{DA RAZOABILIDADE E PROPORCIONALIDADE DA DISPENSA DE REMESSA NECESSÁRIA COM FUNDAMENTO ECONÔMICO NO CÓDIGO PROCESSUAL DE 2015}

Diferentemente das dispensas com fundamento jurisprudencial e por orientação administrativa, a dispensa do $\S^{\circ}$ do art. 496 do CPC/2015 não atende ao interesse público.

Destaca-se que o fundamento econômico de dispensa de remessa necessária foi instituído pela Lei $\mathrm{n}^{\mathrm{o}}$ 10.352/2001, que tratou de uma das várias minirreformas do Código de Processo Civil de 1973. Uma das mudanças mais significativas foi a do reexame necessário do art. 475 do revogado Código de Processo Civil.

Na exposição de motivos do anteprojeto da lei, Athos Gusmão Carneiro e Sálvio de Figueiredo Teixeira defenderam a manutenção do reexame necessário no sistema processual brasileiro, com o escopo de preservar os interesses do Erário - tutelando, consequentemente, patrimônio de toda a sociedade ${ }^{31}$.

${ }^{30}$ LARENZ, Karl apud COELHO, Inocêncio Mártires. Interpretação constitucional. $3^{\mathrm{a}}$ ed. São Paulo: Saraiva, 2007, p. 109.

${ }^{31}$ Exposição de Motivos anteprojeto da Lei n. 10.352: "Não obstante objeções de ordem doutrinária, ainda se apresenta conveniente manter, no sistema processual brasileiro, a o reexame necessário, também 
Revista Eletrônica de Direito Processual - REDP.

Rio de Janeiro. Ano 12. Volume 19. Número 3. Setembro a Dezembro de 2018

Periódico Quadrimestral da Pós-Graduação Stricto Sensu em Direito Processual da UERJ

Patrono: José Carlos Barbosa Moreira (in mem.). ISSN 1982-7636. pp. 138-171

www.redp.uerj.br

A intenção de se estabelecer um limite econômico para a dispensa de remessa necessária era, conforme a exposição de motivos, eliminar o reexame nas causas de valor não excedente a quarenta salários mínimos (modificado posteriormente para sessenta salários). Justificou-se, àquela época, que, em tais casos, eventual defesa do Erário não compensaria a demora e a redobrada atividade procedimental que o reexame impõe, sobrecarregando os tribunais.

O saudoso ministro do STJ levou em conta o princípio da eficiência na atividade administrativa, considerando os custos de todo o sistema de justiça (Poder Judiciário, órgãos da advocacia pública e Ministério Público) para reapreciação de causas de pequenos valor. Ressaltou, por fim, que “os descalabros contra o Erário acontecem, isto sim, nas demandas de grande valor" ${ }^{, 32}$.

O Novo Código de Processo Civil aumentou o limite único de 60 salários mínimos para mínimos para o limite de 1.000 salários mínimos para os entes de direito público federal; 500 salários mínimos para os entes de direito público estadual e Municípios que constituam capitais dos Estados; e 100 salários mínimos para os demais entes de direito público municipal.

Houve, portanto, um acréscimo escalonado no limite único de aproximadamente: 66,66\% para entes de direito público municipal que não constituam capital de Estado; 733,3\% para os entes de direito público estadual e Municípios que constituam capitais dos Estados; e 1566,6\% para os entes de direito público federal.

impropriamente nominado "recurso de ofício', tendo em vista melhor preservar os interesses do erário, tutelando patrimônio que é em última análise, de todos os cidadãos. Todavia, a bem da eficiência do processo, algumas alterações são alvitradas, a fim de: a) eliminar sua incidência nas ações anulatórias de casamento, pois nelas o reexame necessário não mais apresenta qualquer sentido, em sistema jurídico que passou a admitir o divórcio a vínculo; b) corrigir erro de técnica, substituindo a referência à "improcedência da execução" de divida ativa da Fazenda, pela correta menção à "procedência dos embargos" opostos à execução da dívida ativa. Procedentes ou improcedentes são sempre os embargos do executado, não a execução propriamente dita, na qual o contraditório se apresenta mínimo;

c) eliminar o reexame nas causas de valor não excedente a quarenta salários mínimos, nas quais eventual defesa do erário não compensa a demora e a redobrada atividade procedimental que o reexame necessariamente impõe, sobrecarregando os tribunais. Os descalabros contra o erário acontecem, isto sim, nas demandas de grande valor;

d) também não se justifica o reexame quando a sentença estiver fundada em jurisprudência do plenário do Supremo Tribunal Federal (v.g, ações diretas de inconstitucionalidade), ou súmula deste Tribunal ou do tribunal superior competente. Em tais casos, aliás a própria Administração tem baixado instruções a seus procuradores dispensando a interposição de apelação, providência essa todavia inoperante se for mantido o reexame de ofício".

32 Idem. 
Não há como dizer que tais acréscimos atendem ao interesse coletivo ou ao princípio da eficiência administrativa. De fato, o aumento de tais limites possui o escopo de inviabilizar a remessa necessária e fortalecer uma ideia de igualdade estritamente processual entre a Fazenda Pública e o particular - inclusive possibilitando a majoração dos honorários, caso a Fazenda Pública entenda que deva recorrer da sentença condenatória ( $\S \S 1^{\circ}$ e 11 do art. 85 do CPC/2015).

Poder-se-ia alegar que o duplo grau de jurisdição obrigatório em favor da Fazenda Pública é uma mera criação do legislador infraconstitucional (embora muita antiga) sem qualquer menção no texto da Constituição Federal, podendo ser suprimido livremente do ordenamento jurídico processual brasileiro.

A remessa necessária, no entanto, embora não prevista na Constituição Federal, configura decorrência lógica dos princípios constitucionais da supremacia do interesse público e indisponibilidade do interesse público. Mesmo que o reexame necessário seja criação do legislador infraconstitucional, o seu escopo é defender o Erário - que deve ser preservado enquanto garantidor de políticas públicas sociais.

Sobre a questão, Barbosa Moreira ${ }^{33}$ vindicava, sobre a égide do Código anterior, "a inconveniência de eliminar o art. 475 em qualquer reforma futura do estatuto processual. Restrições podem ser admissíveis, e eventualmente dignas de aplauso, desde que justificadas no plano da razoabilidade".

A doutrina contrária ao reexame defende ainda que o recurso voluntário faria com que a remessa necessária perdesse o objeto. Não é o que se verifica na prática. Primeiramente, a devolutividade da matéria pela remessa necessária é plena, enquanto que o recurso voluntário pode ter impugnação parcial ou total. Por conseguinte, ressalta-se o caso de o recurso da Fazenda Pública ser inadmitido - nesse caso, haverá a devolução plena da matéria a ser rediscutida pelo Tribunal no caso de reexame necessário. Ausente o duplo grau de jurisdição obrigatório, entretanto, haverá a simples preclusão do direito de rediscutir a matéria.

Outra questão que extrapola os limites da razoabilidade é o fato de uma sentença ilíquida de baixo valor estaria sujeita à remessa necessária, enquanto uma sentença de

\footnotetext{
${ }^{33}$ MOREIRA, José Carlos Barbosa. Em defesa da revisão obrigatória das sentenças contrárias à Fazenda Pública. Revista do Instituto de Pesquisas e Estudos, Bauru, n. 44, p. 79-88, set./ dez. 2005. p. 210.
} 
Revista Eletrônica de Direito Processual - REDP.

Rio de Janeiro. Ano 12. Volume 19. Número 3. Setembro a Dezembro de 2018

Periódico Quadrimestral da Pós-Graduação Stricto Sensu em Direito Processual da UERJ

Patrono: José Carlos Barbosa Moreira (in mem.). ISSN 1982-7636. pp. 138-171

www.redp.uerj.br

condenação líquida exorbitante (por exemplo, 1.000 salários mínimos, no caso da União) estaria excluída de tal reexame.

Destaca-se a remessa necessária prevista no $\S 1^{\circ}$ do art. 14 da Lei de Mandado de Segurança (Lei $n^{\circ}$ 12.016/2009), que estabelece que haverá a remessa necessária nos casos de concessão de segurança. Diferentemente do duplo grau de jurisdição obrigatório previsto no Código de Processo Civil, a Lei $n^{\circ} 12.016$ não prevê casos de dispensa. Entende o STJ que a regra especial do rito do mandado de segurança, em que inexistem casos de dispensa de remessa necessária, prevalece sobre a disciplina genérica do Código de Processo Civil ${ }^{34}$.

Tal interpretação faz com que uma sentença de mandado de segurança, concedendo, por exemplo, a correção de uma nota de concurso (independente de qualquer nomeação posterior), esteja sujeita ao reexame necessário, mesmo que esteja de acordo com a jurisprudência pacífica dos tribunais superiores.

Resta agora analisar o $\$ 3^{\circ}$ do art. 496 do CPC/2015 sob o ângulo do princípio da proporcionalidade. O princípio da proporcionalidade impõe o preenchimento de três importantes elementos: necessidade, adequação e proporcionalidade em sentido estrito.

O aumento dos limites de dispensa econômica é necessário para o ordenamento jurídico processual enquanto instrumento de celeridade processual e justiça?

Se for analisado somente para o tempo de formação do título executivo judicial definitivo, de maneira endoprocessual, talvez seja mais célere. Em relação à justiça e a efetiva satisfação da pretensão, entretanto, a resposta é negativa, porquanto o título executivo entraria para a longa e demorada lista de espera dos precatórios judiciais.

Ainda que assim não fosse, a celeridade processual não pode ser um fim em si mesmo. Se uma justiça morosa fere a constituição, daí não se retira a ilação de que uma justiça muito rápida seja necessariamente uma benéfica ${ }^{35}$.

\footnotetext{
${ }^{34}$ REsp 1240710/PR, Dje 12/05/2011

${ }^{35}$ MOREIRA, José Carlos Barbosa. O futuro da justiça: alguns mitos. Revista de Processo, Rio de Janeiro, v. 102, abr-jun. 2001. p. 232: Para muita gente, na matéria, a rapidez constitui o valor por excelência, quiçá o único. Seria fácil invocar aqui um rol de citações de autores famosos, apostados em estigmatizar a morosidade processual. Não deixam de ter razão, sem que isso implique - nem mesmo, quero crer, no pensamento dos próprios autores - hierarquização rígida que não reconheça como imprescindível, aqui e ali, ceder o passo a outros valores. Se uma justiça lenta demais é decerto uma justiça má, daí não se segue que uma justiça muito rápida seja necessariamente uma justiça boa. O que todos devemos querer é que a prestação jurisdicional venha a ser melhor do que é. Se para torná-la melhor é preciso acelerá-la, muito bem: não, contudo, a qualquer preço.
} 
Revista Eletrônica de Direito Processual - REDP.

Rio de Janeiro. Ano 12. Volume 19. Número 3. Setembro a Dezembro de 2018

Periódico Quadrimestral da Pós-Graduação Stricto Sensu em Direito Processual da UERJ

Patrono: José Carlos Barbosa Moreira (in mem.). ISSN 1982-7636. pp. 138-171

www.redp.uerj.br

Linda-se que a satisfação da pretensão contida no título judicial é prejudicada pelos novos limites de dispensa de remessa necessária, ferindo o princípio da efetividade. Isso ocorre em razão da dificuldade histórica que os Estados e Municípios possuem para adimplir seus precatórios.

Ressalta-se que a redação original do artigo 100 da Constituição Federal sofreu, após a promulgação da Carta, quatro emendas constitucionais: EC 20/98, EC 30/2000, EC 37/2002 e a EC 62/2009. Em 2010, o CNJ editou a resolução 115 - que, dentre outros aspectos, concedeu o prazo de 15 anos aos Estados federados, Municípios e Distrito Federal para solverem os precatórios vencidos.

Em relação ao aspecto da celeridade e sobrecarga de processos nos tribunais, deve-se considerar que dificilmente um ente federativo deixará de recorrer de uma condenação de valor exorbitante, mesmo que dentro dos limites econômicos da dispensa. Uma condenação de determinado Estado em 300 salários mínimos dificilmente será aceita pelos órgãos de advocacia pública, que obrigarão o Tribunal competente a apreciar recurso de alguma forma.

A norma presente no $\S 3^{\circ}$ do art. 496 do CPC/2015 também não é adequada. Considerando que os títulos executivos judiciais condenatórios em quantia certa de grande valor serão invariavelmente convertidos em precatórios, o propósito de celeridade do $\S 3^{\circ}$ do art. 496 do CPC/2015 perde o sentido. Títulos judiciais passam a ser obtidos mais rapidamente, mas sem satisfazer efetivamente às pretensões financeiras neles contida ${ }^{36}$.

Acesso à justiça é receber a sua prestação em tempo hábil. Em nada adianta uma justiça célere se a pessoa tiver que esperar décadas para o pagamento de seu precatório. Acesso à justiça não é ter um título executivo judicial de forma célere, mas obter a satisfação do seu direito de forma célere (o pagamento do precatório, no caso). Nesse sentido, o reexame necessário consegue reverter injustiças em prol do interesse público,

\footnotetext{
${ }^{36}$ DONIZETTI, Elpídio. Curso Didático de Direito Processual. 19a. ed. São Paulo: Gen, 2016, p.115: "De acordo com o princípio da efetividade, àquele que tem razão, o processo deve garantir e conferir, na medida do possível, justamente o bem da vida a que ele teria direito se não precisasse se valer do processo. Por essa razão, o princípio da efetividade é também denominado de princípio da máxima coincidência possível. Assim como o princípio da celeridade, o processo efetivo não se limita ao provimento formal: a efetividade abrange também (e principalmente) os meios executivos capazes de concretizar o direito material (efetividade em sentido estrito). Vale destacar, no entanto, que processo efetivo não é sinônimo de processo célere. O processo efetivo perdurará pelo prazo compatível com a complexidade do direito discutido. Será célere sempre quanto possível".
} 
Rio de Janeiro. Ano 12. Volume 19. Número 3. Setembro a Dezembro de 2018

Periódico Quadrimestral da Pós-Graduação Stricto Sensu em Direito Processual da UERJ

Patrono: José Carlos Barbosa Moreira (in mem.). ISSN 1982-7636. pp. 138-171 www.redp.uerj.br

eliminando a possibilidade de condenações injustas em valores absurdos precluírem em primeiro grau.

Há outros meios de se conseguir celeridade nas causas envolvendo entes de direito público. Deve o ente público primar pela instituição de câmaras de acordo e conciliação mediante a edição de leis autorizativas. Ressalta-se ainda a via das soluções extrajudiciais de lides, como previsto na Lei ${ }^{\circ} 13.140 / 2015$, que prevê a autocomposição de conflitos no âmbito da Administração Pública.

O próprio inciso IV do $\S 4^{\circ}$ do Código Processual, que prevê a dispensa de remessa necessária por orientação administrativa, é um instrumento de cooperação da Administração Pública para a obtenção de uma tutela efetiva, célere e adequada dispensando-a, inclusive, de apresentar defesa em determinados processos.

É importante destacar que um tribunal exacerbado de processos não é de interesse da Fazenda Pública, em razão de diversos fatores: a) quaisquer deficiências estruturais que impeçam o Poder Judiciário de exercer sua função de forma minimamente satisfatória geram encargos financeiros para os entes públicos; b) os processos judiciais cujo êxito é de interesse do Poder Público também sofrem com a demora; e c) o excesso de trabalho acaba prejudicando na qualidade da prestação jurisdicional.

A análise da proporcionalidade em sentido estrito resta prejudicada. De fato, o aumento dos limites econômicos de remessa necessária não é medida necessária nem adequada para a obtenção da celeridade processual, ferindo outros valores constitucionais.

Há desrespeito à razoabilidade, pois o legislador processual também está limitado aos preceitos da moderação e da racionalidade. $\mathrm{O}$ acesso à justiça é ferido, porquanto a inviabilização do reexame necessário em condenações de grande valor e o consequente aumento da dívida de precatórios retardam ainda mais a satisfação de um legítimo direito (e não apenas um título executivo oriundo de uma preclusão processual).

Não se observa, também, o interesse público, visto que o Erário é a fonte de custeio dos direitos fundamentais e deve ser tutelado como tal. Por fim, ressalta-se uma lesão à autonomia financeira dos Estados e Municípios, que terão sua dívida de precatórios ampliada por ato unilateral da União. 
Rio de Janeiro. Ano 12. Volume 19. Número 3. Setembro a Dezembro de 2018

Periódico Quadrimestral da Pós-Graduação Stricto Sensu em Direito Processual da UERJ

Patrono: José Carlos Barbosa Moreira (in mem.). ISSN 1982-7636. pp. 138-171 www.redp.uerj.br

\section{DO PACTO FEDERATIVO E AUTONOMIA FINANCEIRA DOS ESTADOS, MUNICÍPIOS E DISTRITO FEDERAL}

Uma questão que merece atenção é a possibilidade de a União, a pretexto de estar dentro de sua competência legislativa em matéria de direito processual (art. 22, I, da CF), poder elaborar norma unilateralmente que acarrete o aumento da dívida dos Estados, Distrito Federal e Municípios. É justamente o caso das novas dispensas de remessa necessária previstas no $\S^{\circ}$ do art. 496 do CPC/2015.

A República Federativa do Brasil é formada pela união indissolúvel dos Estados e Municípios e do Distrito Federal, conforme o caput do artigo $1^{\circ}$ da Constituição. Cuida-se da norma matriz do modelo federativo brasileiro. No art. 18 da Carta, é expressamente concedido aos entes federativos a autonomia nos seguintes aspectos: auto-organização, normatização própria, autogoverno e autoadministração.

O pacto federativo, portanto, baseia-se no princípio da autonomia e da participação política, pressupondo a consagração de certas regras constitucionais, tendentes não somente à sua configuração, mas também à sua manutenção e indissolubilidade. Dentre as diversas faces da autonomia, encontra-se a autonomia financeira, que garante aos entes federativos competências tributárias e capacidade de gerir suas rendas ${ }^{37}$.

No campo da autonomia financeira, o Supremo Tribunal Federal já teve oportunidades de julgar determinados atos normativos editados pela União como inconstitucionais. Em tais oportunidades, julgaram-se inconstitucionais atos normativos da União que, a pretexto de editarem normas gerais, configurem verdadeira ingerência na autonomia financeira dos entes federativos ${ }^{38}$.

Defende-se, neste trabalho, que a norma processual que alterou os limites de remessa necessária extrapolou os limites da norma processual, acarretando uma possibilidade real de gradação das dívidas de precatórios dos Estados, DF e Municípios. Destaca-se que, conforme o $\$ 7^{\circ}$ do art. 30 da Lei de Responsabilidade Fiscal, os precatórios judiciais não pagos durante a execução do orçamento em que houverem sido incluídos integram a dívida consolidada.

\footnotetext{
${ }^{37}$ MORAES, Alexandre de. Direito Constitucional. 28ª Ed. São Paulo: atlas, 2012, p. 286.

${ }^{38}$ ACO 1.062/DF AgR, rel. min. Ricardo Lewandowski, j. 13-8-2014; ACO 830/PR e AC 3.201-MC/PR, Rel. Min. Marco Aurélio; AC 3.562/MG e ACO 2.421/MG, Rel. Min. Cármen Lúcia; e AC 3.608-MC/RR, Rel. Min. Dias Toffoli.
} 
Revista Eletrônica de Direito Processual - REDP.

Rio de Janeiro. Ano 12. Volume 19. Número 3. Setembro a Dezembro de 2018

Periódico Quadrimestral da Pós-Graduação Stricto Sensu em Direito Processual da UERJ

Patrono: José Carlos Barbosa Moreira (in mem.). ISSN 1982-7636. pp. 138-171

www.redp.uerj.br

De fato, há um reconhecimento histórico, por parte de todos os setores do governo

e da sociedade, referente à dificuldade dos entes públicos em adimplirem suas dívidas consubstanciadas em precatórios.

Reitera-se que a redação original do artigo 100 da Constituição Federal sofreu, após a promulgação da Carta, quatro emendas constitucionais (EC 20/98, EC 30/2000, EC 37/2002 e a EC 62/2009).

A Suprema Corte, na ADI 4425/DF, julgou diversos dispositivos da EC 62/2009 inconstitucionais por ferirem direitos fundamentais no regime de precatórios. No julgamento da modulação de efeitos de tal ação, no entanto, houve o reconhecimento da fragilidade financeira dos entes para quitação dos precatórios vencidos, mantendo diversas disposições da norma tida como inconstitucional por certo lapso de tempo ${ }^{39}$.

Considerando essa inadimplência histórica no pagamento de precatórios e o texto do $\S 3^{\circ}$ do art. 496 do CPC vigente, é uma ingenuidade acreditar que todos os entes de mesmo nível federativo possuem a mesma capacidade de honrar com as dívidas judiciais. No campo processual, deve haver cautela com medidas que acarretam ônus financeiros ao Poder Público.

${ }^{39}$ ADI 4425 QO, Relator(a): Min. LUIZ FUX, Tribunal Pleno, julgado em 25/03/2015, PROCESSO ELETRÔNICO DJe-152 DIVULG 03-08-2015 PUBLIC 04-08-2015: In casu, modulam-se os efeitos das decisões declaratórias de inconstitucionalidade proferidas nas ADIs $\mathrm{n}^{\circ} 4.357$ e 4.425 para manter a vigência do regime especial de pagamento de precatórios instituído pela Emenda Constitucional $n^{\circ}$ 62/2009 por 5 (cinco) exercícios financeiros a contar de primeiro de janeiro de 2016. 3. Confere-se eficácia prospectiva à declaração de inconstitucionalidade dos seguintes aspectos da $\mathrm{ADI}$, fixando como marco inicial a data de conclusão do julgamento da presente questão de ordem (25.03.2015) e mantendo-se válidos os precatórios expedidos ou pagos até esta data, a saber: (i) fica mantida a aplicação do índice oficial de remuneração básica da caderneta de poupança (TR), nos termos da Emenda Constitucional no 62/2009, até 25.03.2015, data após a qual (a) os créditos em precatórios deverão ser corrigidos pelo Índice de Preços ao Consumidor Amplo Especial (IPCA-E) e (b) os precatórios tributários deverão observar os mesmos critérios pelos quais a Fazenda Pública corrige seus créditos tributários; e (ii) ficam resguardados os precatórios expedidos, no âmbito da administração pública federal, com base nos arts. 27 das Leis $n^{\circ} 12.919 / 13$ e $\mathrm{n}^{\circ}$ 13.080/15, que fixam o IPCA-E como índice de correção monetária. 4. Quanto às formas alternativas de pagamento previstas no regime especial: (i) consideram-se válidas as compensações, os leilões e os pagamentos à vista por ordem crescente de crédito previstos na Emenda Constitucional $\mathrm{n}^{\circ}$ 62/2009, desde que realizados até 25.03.2015, data a partir da qual não será possível a quitação de precatórios por tais modalidades; (ii) fica mantida a possibilidade de realização de acordos diretos, observada a ordem de preferência dos credores e de acordo com lei própria da entidade devedora, com redução máxima de $40 \%$ do valor do crédito atualizado. 5. Durante o período fixado no item 2 acima, ficam mantidas (i) a vinculação de percentuais mínimos da receita corrente líquida ao pagamento dos precatórios (art. 97, § 10, do ADCT) e (ii) as sanções para o caso de não liberação tempestiva dos recursos destinados ao pagamento de precatórios (art. 97, §10, do ADCT). 6. Delega-se competência ao Conselho Nacional de Justiça para que considere a apresentação de proposta normativa que discipline (i) a utilização compulsória de $50 \%$ dos recursos da conta de depósitos judiciais tributários para o pagamento de precatórios e (ii) a possibilidade de compensação de precatórios vencidos, próprios ou de terceiros, com o estoque de créditos inscritos em dívida ativa até 25.03.2015, por opção do credor do precatório. 7. Atribui-se competência ao Conselho Nacional de Justiça para que monitore e supervisione o pagamento dos precatórios pelos entes públicos na forma da presente decisão. 
Revista Eletrônica de Direito Processual - REDP.

Rio de Janeiro. Ano 12. Volume 19. Número 3. Setembro a Dezembro de 2018

Periódico Quadrimestral da Pós-Graduação Stricto Sensu em Direito Processual da UERJ

Patrono: José Carlos Barbosa Moreira (in mem.). ISSN 1982-7636. pp. 138-171

www.redp.uerj.br

Na seara das finanças públicas, destaca-se o dever de observância do federalismo de cooperação, que é a forma de unir os entes desiguais. Nesse modelo de federação, as atribuições serão exercidas de modo comum ou concorrente, estabelecendo-se uma verdadeira aproximação entre os entes federativos. As unidades federativas devem atuar em conjunto, fortalecendo o Estado Democrático de Direito ${ }^{40}$.

Os limites de dispensa econômica de reexame necessário do CPC/2015 prescindem do fato de que diferentes governos estaduais e municipais encontram-se em situações fiscais muito distintas entre si, considerando condicionantes históricas, econômicas, sociais e administrativas. Se determinado governo estadual conseguisse quitar seus precatórios em poucos anos, isto seria um fato isolado, que não se repetiria na grande maioria dos Estados, muito menos nas prefeituras, não podendo supor que a exceção seja a regra.

No ano de 2013, a FGV/IBRE soltou uma nota técnica referente ao impacto dos precatórios nos orçamentos públicos, considerando a emenda constitucional n ${ }^{\circ}$ 62/2009 e o julgamento das ADIN's no 4.357 e 4.425 pelo STF. Àquela época, alguns levantamentos já eram alarmantes, deixando evidente a delicada situação dos Estados perante suas dívidas judiciais $^{41}$.

\footnotetext{
${ }^{40}$ LENZA, Pedro. Curso de Direito Constitucional. 16. ${ }^{a}$ Ed. São Paulo: Saraiva, 2012, p. 420.

${ }^{41}$ Da amostra trabalhada, $62 \%$ dos Estados sugerem ter condições para se ajustar ao limite de 15 anos para quitação dos precatórios; $54 \%$ realizam leilões ou acordos e apenas 7,7\% utilizam crédito tributário. Os Estados Top 5 no ranking dos principais devedores são, respectivamente: São Paulo (R \$ 16,5 bilhões), Rio Grande do Sul ( $\mathrm{R} \$ 6,8$ bilhões), Rio de Janeiro ( $\mathrm{R} \$ 4,8$ bilhões), Paraná ( $\mathrm{R} \$ 4,6$ bilhões) e Minas Gerais ( $\mathrm{R} \$$ 3,7 bilhões); Em média, para os 13 maiores litigantes o volume de recursos transferidos para os Tribunais de Justiça (TJ) representou 8\% do estoque de precatórios em 2012. Mantido esse fluxo de recursos, a duração média para zeragem automática do estoque ocorreria em até 12 anos (2025), contados a partir do ano corrente e um ano a mais do que o estabelecido pela Emenda Constitucional 62 de 2009 (EC 62/ 09); Apesar do Estado de São Paulo possuir maior estoque de dívida de precatórios, a alocação de 1,5\% da Receita Corrente Líquida (RCL) - equivalente a um fluxo médio anual de R \$1,6 bilhões - deverá permitir que o Estado quite o passivo atual em até 10 anos (2023), prazo inferior ao da EC 62/09; Ainda que sem regra para pagamento do passivo acumulado até 2012, como por exemplo, razão sobre a RCL o Estado do Rio de Janeiro vem ampliando o volume de recursos para quitação, de forma que mantida o fluxo de cerca de $\mathrm{R} \$ 340$ milhões, deverá quitar seu saldo atual em até 14 anos; Dentre os Top 5, o único Estado cujo atual fluxo de alocação de recursos não deverá conseguir zerar o saldo de precatórios é o Rio Grande Do Sul que deverá experimentar mais 20 anos até quitar seu atual passivo. Para o enquadramento dentro do limite de 15 anos é necessário que sua RCL apresente importante crescimento, de forma a permitir que a atual regra de 1,5\% sobre a RCL, seja suficiente para que o Estado se ajuste ao limite da EC 62/09; Os demais Estados de Santa Catarina, Piauí e Rio Grande do Norte, somam-se ao Rio Grande do Sul no grupo daqueles que, mantidos os atuais fluxos de pagamentos, não deverão convergir para o limite da EC 62/09, de 15 anos, para zeragem do estoque de precatórios. Dentre os 13 Estados, destaca-se positivamente o Espírito Santo que em aproximadamente 4 anos deverá ser capaz de quitar o saldo de precatórios, se mantido o fluxo médio anual de $\mathrm{R} \$ 200$ milhões de pagamento.
} 
Revista Eletrônica de Direito Processual - REDP.

Rio de Janeiro. Ano 12. Volume 19. Número 3. Setembro a Dezembro de 2018

Periódico Quadrimestral da Pós-Graduação Stricto Sensu em Direito Processual da UERJ

Patrono: José Carlos Barbosa Moreira (in mem.). ISSN 1982-7636. pp. 138-171

www.redp.uerj.br

Uma questão alarmante é que esse estudo é datado de 2013, momento em que o

Brasil não havia entrado em recessão econômica, ainda. Conforme dados do IBGE (Ipeadata), entre 2014 e 2016, o PIB brasileiro contraiu em 7,9\%. Considerando o impacto dessa contração na receita corrente líquida dos entes federados, é seguro afirmar que o prazo previsto pelo estudo da FGV para a quitação dos precatórios aumentou para quase que a totalidade dos Estados analisados.

Além da ofensa ao pacto federativo, pode-se olhar o $§ 3^{\circ}$ do art. 496 do Código Processual sob o aspecto da inconstitucionalidade circunstancial. Ainda que fosse a norma válida em tese, ao ser confrontada com determinadas circunstâncias concretas, estaríamos diante de uma incompatibilidade com a constituição ${ }^{42}$. Levando em conta a grande recessão econômica pela qual o país passa e a dificuldade histórica que os entes federativos possuem de solver seus débitos de precatórios, pode-se afirmar a inconstitucionalidade de qualquer medida tendente a agravar a já calamitosa situação financeira dos entes públicos, mesmo que aparentemente processual.

O artigo que outorga à União a competência de legislar sobre matéria processual (art. 22, I, da CF) não pode ser interpretado de maneira absoluta e ilimitada. Destaca-se a situação de fato materialmente insuperável: deve haver um contingenciamento das dívidas judiciais, porquanto inexistem disponibilidades de caixa suficientes para o pagamento integral dos precatórios.

O intérprete discerne o sentido do texto constitucional a partir e em virtude de um determinado caso dado. Assim, a norma jurídica é por ele reproduzida não apenas a partir de elementos colhidos no texto normativo (mundo do dever-ser), mas igualmente a partir de elementos concretos do caso ao qual será ela aplicada - ou seja, a partir de dados da realidade (mundo do ser) ${ }^{43}$.

\footnotetext{
42 BARCELLOS, Ana Paula de. Ponderação, racionalidade e atividade jurisdicional, Rio de Janeiro: Renovar, 2005, p. 231 -232: "Trata -se da declaração de inconstitucionalidade da norma produzida pela incidência da regra sobre uma determinada situação específica [...] É possível cogitar de situações nas quais um enunciado normativo, válido em tese e na maior parte de suas incidências, ao ser confrontado com determinadas circunstâncias concretas, produz uma norma inconstitucional. Lembre -se que, em função da complexidade dos efeitos que se pretendam produzir e/ou da multiplicidade de circunstâncias de fato sobre as quais incidem, também as regras podem justificar diferentes condutas que, por sua vez, vão dar conteúdo a normas diversas. Cada uma dessas normas opera em um ambiente fático próprio e poderá ser confrontada com um conjunto específico de outras incidências normativas, justificadas por enunciados diversos. Por isso, não é de estranhar que determinadas normas possam ser inconstitucionais em função desse seu contexto particular, a despeito da validade geral do enunciado do qual derivam".

43 GRAU, Eros Roberto. A emenda constitucional n. 30/00: pagamento de precatórios judiciais. Revista de Direito Administrativo, Rio de Janeiro, 229, jul-set. 2002, p. 93.
} 
Rio de Janeiro. Ano 12. Volume 19. Número 3. Setembro a Dezembro de 2018

Os Estados e Municípios encontram-se diante de autêntico estado de necessidade: os pagamentos de precatórios devidos não podem ser realizados, devendo encontrar meios de não aumentarem suas dívidas judiciais.

Denota-se a exposição de Konrad Hesse a respeito da força normativa da Constituição. A norma constitucional não tem existência autônoma em face da realidade. Segundo Hesse, a Constituição jurídica está condicionada pela realidade histórica, não podendo ser separada da realidade concreta do seu tempo. Poder nenhum do mundo, nem mesmo a Constituição, pode alterar as condicionantes naturais ${ }^{44}$. Ademais, é notório que não se interpreta a Constituição em tiras ou pedaços. Isto porque jamais se aplica uma norma jurídica de maneira isolada, mas a própria Constituição no seu todo. Interpretar é, logo, dar concreção ao direito. Neste sentido, a interpretação opera a inserção do direito na realidade - opera a mediação entre o caráter geral do texto normativo e sua aplicação particular. "Em outros termos, ainda: vai do universal ao particular, do transcendente ao contingente; opera a inserção do direito no mundo da vida"45.

Os mais prejudicados pela norma processual questionada são os Municípios. O Código de Processo Civil pressupõe que todos os Municípios que não sejam capitais de Estado possuem igual capacidade financeira. Há Municípios cujo PIB não ultrapassa 100 salários-mínimos $^{46}$, não havendo como afirmar que tal valor seja disponível conforme o interesse público do Município.

A fragilidade processual dos Municípios pequenos não é uma questão nova. $\mathrm{O}$ Projeto de Lei $\mathrm{n}^{\mathrm{o}} 3.533 / 2004$ previa a remessa necessária apenas nos casos em que a sentença fosse desfavorável aos Municípios com população igual ou inferior a um milhão de habitantes.

Evidente que somente Municípios maiores possuem órgão de representação judicial minimamente estruturados, sem contar que a maioria sequer possui quadro próprio de procuradores aprovados por concurso público. Municípios menores se veem obrigados a contratar escritórios privados de advocacia, cuja escolha e procedimento licitatório ficam limitados às disponibilidades financeiras do ente federativo.

\footnotetext{
${ }^{44}$ HESSE, Konrad. A forca normativa da Constituição. Porto Alegre: Sérgio Antônio Fabris, 1991, p. 24.

45 GRAU, Eros Roberto. Op. cit. p. 88-98.

${ }^{46}$ IBGE - Instituto Brasileiro de Geografia e Estatística.
} 
Rio de Janeiro. Ano 12. Volume 19. Número 3. Setembro a Dezembro de 2018

Periódico Quadrimestral da Pós-Graduação Stricto Sensu em Direito Processual da UERJ

Patrono: José Carlos Barbosa Moreira (in mem.). ISSN 1982-7636. pp. 138-171 www.redp.uerj.br

As novas dispensas econômicas de remessa necessária, portanto, são inconstitucionais também por serem incompatíveis com a realidade de fato do país e por ferirem ao pacto federativo.

\section{PROPOSIÇÕES LEgislativas PARA OTIMIZAÇÃo DA REMESSA NECESSÁRIA NO ORDENAMENTO JURÍDICO BRASILEIRO}

Com o escopo de otimizar o sistema de remessa necessária, algumas mudanças poderiam ser efetuadas.

Primeiramente, defende-se a extensão das dispensas do $\$ 4^{\circ}$ do art. 496 Código de Processo Civil à remessa necessária prevista no $\S 1^{\circ}$ do art. 14 da Lei de Mandado de Segurança (Lei n ${ }^{\circ}$ 12.016/2009).

$\mathrm{O}$ rito especial do mandado de segurança estabelece que haverá a remessa necessária nos casos de concessão de segurança. A adição das dispensas com fundamento jurisprudencial e de orientação administrativa seria uma medida que atenderia aos princípios da celeridade e eficiência na prestação jurisdicional. Tal questão configuraria uma superação legislativa do posicionamento do STJ, que entende que a regra especial do rito do mandado de segurança, em que inexiste casos de dispensa de remessa necessária, prevalece sobre a disciplina genérica do Código de Processo Civil ${ }^{47}$.

Sobre a questão, linda-se o Enunciado 312 do Fórum Permanente de Processualistas Civis, que vindica que as dispensas por orientação administrativa seriam aplicáveis à remessa necessária no rito do writ.

Outra resposta legislativa à ineficiência do sistema de reexame necessário seria, além de uma previsão expressa, a extensão das dispensas jurisprudenciais do $\S 4^{\circ}$ do art. 496 Código de Processo Civil ao rito das Ações Civis Públicas. Há casos em que a questão fática é incontroversa, restando apenas a interpretação jurídica do fato no caso concreto.

Casos em que a dispensa seria possível: determinado contrato de plano de saúde cujas cláusulas o STJ já declarou não serem ilegais, inexistindo dano moral coletivo $^{48}$; a impossibilidade de o Ministério Público ajuizar demandas discutindo a relação jurídico-

\footnotetext{
${ }^{47}$ REsp 1240710/PR, Dje 12/05/2011.

${ }^{48}$ REsp 1473846/SP, DJe 24/02/2017, e REsp 1293606/MG, DJe 26/09/2014.
} 
Revista Eletrônica de Direito Processual - REDP.

Rio de Janeiro. Ano 12. Volume 19. Número 3. Setembro a Dezembro de 2018

Periódico Quadrimestral da Pós-Graduação Stricto Sensu em Direito Processual da UERJ

Patrono: José Carlos Barbosa Moreira (in mem.). ISSN 1982-7636. pp. 138-171

www.redp.uerj.br

tributária $^{49}$; e ilegitimidade ativa do Ministério Público para, na qualidade de substituto processual de menores carentes, propor Ação Civil Pública ex delicto, sem a anterior intimação da Defensoria Pública para tomar ciência da ação ${ }^{50}$.

Ressalta-se que o Superior Tribunal de Justiça vem, à despeito da ausência de previsão legal, aplicando o instituto da remessa necessária às Ações Civis Públicas (ACPs), em interpretação analógica ao artigo 19 da Lei $n^{\circ}$ 4.717/65 - Lei da Ação Popular ${ }^{51}$. Em tais casos, a sentença que concluir pela carência ou pela improcedência da ação estará sujeita ao duplo grau de jurisdição, exceto nas ações de improbidade administrativa ${ }^{52}$.

Cuida-se de um entendimento contraditório à visão restritiva que o STJ adotou quando da interpretação das dispensas de remessa necessária no rito de mandado de segurança. A Corte Superior aplicou analogicamente a remessa necessária do rito da Ação Popular ao rito da Ação Civil Pública, mas negou a aplicação das dispensas de reexame necessário do CPC ao rito de Mandado de segurança.

Por fim, aponta-se uma solução legislativa que seria essencial para tutelar o pacto federativo e as disponibilidades financeiras de cada Estado, Município e Distrito Federal: a possibilidade de a lei processual da União prever que cada Estado e Município possa estabelecer seu limite econômico para a remessa necessária, conforme os arts. 24, XI, e 30, II, da Constituição Federal.

Para tanto, é necessário traçar limites entre normas processuais ${ }^{53}$ (competência da União) e normas procedimentais ${ }^{54}$ (competência concorrente). A competência legislativa

\footnotetext{
${ }^{49}$ REsp 1541275/PR, DJe 18/12/2015.

${ }^{50}$ REsp 888.081/MG, DJe 18/10/2016.

${ }^{51}$ REsp 1220667/MG; AgInt no AREsp 949377/MG.

${ }^{52}$ REsp 1.220.667-MG, julgado em 4/9/2014.

${ }^{53} \mathrm{Na}$ análise das competências legislativas em questão, é imprescindível a adoção da teoria do processo como relação jurídica. Elpídio Donizetti, Curso Didático de Direito Processual, 2016, p.194: “processo é o método pelo qual se opera a jurisdição, com vistas à composição dos litígios. É instrumento de realização da justiça; é relação jurídica, portanto, é abstrato e finalístico. Procedimento é o modus faciendi, o rito, o caminho trilhado pelos sujeitos do processo. Enquanto o processo constitui o instrumento para a realização da justiça, o procedimento constitui o instrumento do processo, a sua exteriorização". Para fins de repartição de competências federativas, tal distinção entre processo e procedimento restaria prejudicada se fosse adotada teoria diversa.

54 Denota-se, entretanto, o fortalecimento da teoria do processo como procedimento em contraditório, oriundo de Elio Fazzalari, no CPC/2015. Conforme tal teoria, o procedimento "é uma série ou sequência de normas, atos e posições subjetivas que se conectam e inter-relacionam em um complexo normativo próprio, constituindo a fase preparatória e obrigatória de um provimento (ato final de caráter imperativo). Dessa forma, 'não só o ato final, em sua existência, mas a própria validade desse ato, e consequentemente, sua eficácia, dependem do correto desenvolvimento do procedimento'. O processo, por sua vez, seria uma espécie do gênero procedimento, qualificado justamente pelo contraditório, quer dizer, pela abertura à participação das partes, em simétrica paridade, na formação do provimento final (sentença ou acórdão)"
} 
Revista Eletrônica de Direito Processual - REDP.

Rio de Janeiro. Ano 12. Volume 19. Número 3. Setembro a Dezembro de 2018

Periódico Quadrimestral da Pós-Graduação Stricto Sensu em Direito Processual da UERJ

Patrono: José Carlos Barbosa Moreira (in mem.). ISSN 1982-7636. pp. 138-171

www.redp.uerj.br

federal para matéria processual decorre do interesse nacional e da necessidade de

uniformização de legislação processual, sob pena de sacrificar a segurança jurídica.

A norma processual possui um aspecto de uniformidade e segurança jurídica no território brasileiro, enquanto a norma procedimental foi feita para atender às peculiaridades de cada Estado. Procedendo uma interpretação sistemática da Constituição, nota-se a primazia da uniformização de interpretação da norma: previsão de Tribunais Superiores encarregados de uniformização de interpretação em território nacional (arts. 101 a 124); previsão constitucional de diversos que tutelam o direito objetivo e sua interpretação uniforme (arts. 102, III; 105, III; 121, §4), súmulas vinculantes (art. 103-A) e instrumentos de controle concentrado de constitucionalidade (arts. 102, I, “a”, e $\S 3^{\circ}$; 103). Os valores tutelados por tal uniformidade são: isonomia, justiça e segurança jurídica.

Esse aspecto de uniformidade de legislação processual não prejudica, entretanto, a possibilidade de Estados e Distrito Federal legislarem concomitantemente sobre normas procedimentais $^{55}$.

(Elpídio Donizetti, op. cit, p.198). Fredie Didier Jr, por sua vez, encontra um ponto de equilíbrio entre as teorias: "note-se que, para encarar o processo como um procedimento (ato jurídico complexo de formação sucessiva), ou, ainda como um procedimento em contraditório, segundo a visão de Fazzalari, não se faz necessário abandonar a ideia de ser o processo, também uma relação jurídica. O termo 'processo' serve, então, tanto para designar o ato processo como a relação jurídica que dele emerge. $\mathrm{O}$ art. 14 do CPC ratifica essa compreensão sobre o processo: 'A norma processual não retroagirá e será aplicável imediatamente aos processos em curso, respeitados os atos processuais praticados e as situações jurídicas consolidadas sob a vigência da norma revogada'. Observe que o legislador fala em 'atos processuais praticados e as situações jurídicas consolidadas'. Exatamente como ora se propõe” (curso de direito processual civil, volume I, 18 a ed., 2016, p. 35).

${ }^{55}$ Gilmar Mendes leciona sobre a dicotomia legislativa processo/procedimento na ADI 2.922-RJ: "Processo é o instrumento pelo qual o Estado presta a jurisdição, ao passo que procedimento é a forma como o processo é desenvolvido e executado. O direito processual cuida da unidade, da série de atos pelos quais se dá a prestação jurisdicional. O procedimento, por sua vez, é a ordem como esses atos serão desenvolvidos, tem relação com sua dinâmica, incluindo-se aí o modo de postular, a estrutura da petição inicial, o modo como serão colhidas provas admitidas pela legislação processual. Na estrutura federativa brasileira, coube à União estabelecer privativamente normas processuais, válidas uniformemente em toda a Federação. À própria União, Estados e Distrito Federal foi concedida a competência concorrente de, utilizando-se de certo grau de autonomia, criar regras procedimentais para melhor execução da legislação processual federal. Os Entes federativos, portanto, têm a prerrogativa de definir a forma como a matéria processual será executada, de acordo com a maneira que julgar ser mais adequada para atender suas peculiaridades, consoante art. 24, §3, da Constituição Federal. Assim, a Constituição Federal, ao incluir ao rol das competências concorrentes a edição de leis que versem sobre procedimentos em matéria processual, garantiu a preservação do poder de os Entes federativos editarem normas que atendam aos seus anseios e características locais, adequando o modo como se desenvolve o processo à sua realidade. Essa previsão está calcada em um principio basilar do sistema federativo, que é o respeito ao pluralismo federal. Ressalto, ainda, que a prerrogativa de legislar sobre procedimentos possui também o condão de transformar os Estados em verdadeiros laboratórios legislativos. Ao conceder-se aos Entes federados o poder de regular o procedimento de uma matéria, baseando-se em peculiaridades próprias, está a possibilitar-se que novas e exitosas experiências sejam formuladas. Os Estados passariam a ser partícipes importantes no desenvolvimento do direito nacional e a atuar ativamente na construção de possíveis experiências que poderão ser adotadas por outros Entes ou em 
Revista Eletrônica de Direito Processual - REDP.

Rio de Janeiro. Ano 12. Volume 19. Número 3. Setembro a Dezembro de 2018

Periódico Quadrimestral da Pós-Graduação Stricto Sensu em Direito Processual da UERJ

Patrono: José Carlos Barbosa Moreira (in mem.). ISSN 1982-7636. pp. 138-171 www.redp.uerj.br

Destarte, ressalta-se que limites econômicos distintos de reexame não quebrariam a uniformidade processual. Os instrumentos de ampla defesa e devido processo legal continuariam resguardados em todo território nacional. Tais limites individualizados por cada ente seriam adequados para melhor atender suas peculiaridades e capacidades financeiras.

Há uma possibilidade razoável de as competências legislativas processuais e procedimentais serem aceitas como constitucionais pelo Supremo Tribunal Federal. A Suprema Corte entende que o princípio federativo vindica a transposição de qualquer interpretação demasiadamente centralizadora das competências normativas da União, permitindo novas searas normativas que possam ser trilhadas pelos Estados-Membros, Municípios e Distrito Federal ${ }^{56}$.

Caso não se entenda ser hipótese de competência do 24, XI, da Carta, poder-se-ia aplicar o parágrafo único do art. 22 da CF. Esse parágrafo permite à União editar lei complementar autorizando Estados e DF a legislarem sobre determinados assuntos de competência legislativa privativa da União (no caso, matéria processual).

Os Municípios, embora não possuam competência para legislar sobre normas procedimentais, poderiam se enquadrar no inciso IV do $\$ 4^{\circ}$ do art. 496 do CPC/2015 e fixar limites por meio de seus órgãos administrativos (art. 30, II, da CF).

Assim, quais seriam os parâmetros mínimos que poderiam ser utilizados para limites econômicos? Invoca-se o art. 87 do ADCT, que determina que, até que sobrevenham as leis específicas dos entes da Federação, serão considerados de pequeno valor, para fins de RPV, os débitos judiciais que tenham valor igual ou inferior a: 40 salários-mínimos, perante a Fazenda dos Estados e do Distrito Federal; e 30 saláriosmínimos, perante a Fazenda dos Municípios.

Considerando que esses limites foram considerados, pelo Poder Constituinte Reformador, em conformidade com a capacidade financeira dos entes federativos, seria

todo território federal" (Gilmar Mendes, ADI 2.922-RJ, julg. 03/04/2014). O Supremo Tribunal Federal, para fins de delimitação de competências legislativas, parece ter adotado a teoria instrumentalista do processo.

${ }^{56}$ Segundo Luiz Fux no julgamento da ADI 2663/RS (rel. Min. Luiz Fux, julgamento em 8.3.2017): “a 'prospective overruling', antídoto ao engessamento do pensamento jurídico, possibilita ao STF rever sua postura em casos de litígios constitucionais em matéria de competência legislativa, viabilizando o prestígio das iniciativas regionais e locais, ressalvadas as hipóteses de ofensa expressa e inequívoca a norma da Constituição". 
Rio de Janeiro. Ano 12. Volume 19. Número 3. Setembro a Dezembro de 2018

razoável que pudessem ser utilizados como limites de reexame necessário na ausência de legislação específica do ente federativo.

Destaca-se, outrossim, a possibilidade de a remessa necessária ser incorporada à Constituição Federal por meio de emenda (art. 60 da $\mathrm{CF}$ ), evitando que maiorias legislativas eventuais tentassem suprimir ou inviabilizar o instituto novamente.

\section{CONCLUSÃO}

O Erário - enquanto instrumento de garantia de direitos que é - deve ter proteção especial para os seus recursos financeiros, porquanto esses proveem os meios para a realização do interesse público primário. Sem as verbas públicas necessárias, o Estado não tem capacidade de promover investimentos sociais nem de executar, de forma adequada, os serviços públicos essenciais para a sociedade.

Não sendo exigência constitucional nem prerrogativa de caráter absoluto em favor da Fazenda, a lei pode mitigar a exigência do reexame necessário, mas sempre em prol do interesse público, atendendo ao princípio da razoabilidade. Destaca-se a louvável evolução nas hipóteses de dispensa com fundamento jurisprudencial, assim como a instituição de dispensa de remessa por orientação administrativa para todos os entes federativos.

O Código de 2015 trouxe uma modificação da remessa necessária bastante prejudicial aos cofres públicos: o $\S 3^{\circ}$ do art. 496, referente à dispensa de remessa necessária com fundamento econômico. O limite passou de um unitário de 60 (sessenta) salários-mínimos para: 1.000 (mil) salários-mínimos para a União e as respectivas autarquias e fundações de direito público; 500 (quinhentos) salários-mínimos para os Estados, o Distrito Federal, as respectivas autarquias e fundações de direito público e os Municípios que constituam capitais dos Estados; e 100 (cem) salários-mínimos para todos os demais Municípios e respectivas autarquias e fundações de direito público. Tal norma, diferentemente das dispensas com fundamento jurisprudencial e por orientação administrativa, não atende ao interesse público.

Embora a remessa necessária seja criação do legislador infraconstitucional, qualquer modificação legislativa nesse ponto deve atender aos princípios da razoabilidade e proporcionalidade. 
Rio de Janeiro. Ano 12. Volume 19. Número 3. Setembro a Dezembro de 2018

No plano da razoabilidade, o Novo Código aumentou de forma temerária os limites econômicos de dispensa de remessa necessária, desvirtuando o seu fundamento: o princípio da eficiência administrativa.

O $\S 3^{\circ}$ do art. 496 do CPC/2015, igualmente, não prospera sob o crivo do princípio da proporcionalidade. Ressalta-se que o aumento dos limites de dispensa econômica não é medida necessária nem adequada para o ordenamento jurídico processual enquanto instrumento de celeridade processual e justiça. A norma somente diminui o tempo de formação do título executivo judicial definitivo. Em relação à justiça e a efetiva satisfação da pretensão, as novas dispensas com fundamento econômico são prejudiciais, pois aumentam as dívidas de precatórios em razão de uma nova regra de preclusões processuais - dificultando ainda mais a satisfação dos débitos devidos pela Fazenda Pública.

Merece atenção a atitude de a União, a pretexto de estar dentro de sua competência legislativa envolvendo normas processuais (art. 22, I, da CF), poder elaborar norma unilateralmente que acarrete o aumento da dívida dos Estados, Distrito Federal e Municípios. É justamente o caso do das novas dispensas de remessa necessária previstas no $\S 3^{\circ}$ do art. 496 do CPC/2015.

Vindica-se que a norma que alterou os limites econômicos de remessa necessária extrapolou os limites da norma processual, acarretando uma perigosa gradação das dívidas de precatórios no futuro, ferindo a autonomia financeira dos entes federativos.

O $\S 3^{\circ}$ do art. 496 do Código Processual pode, outrossim, ser analisado sob o aspecto da inconstitucionalidade circunstancial. Levando em conta a grande recessão econômica pela qual o país passa e a dificuldade histórica que os entes federativos possuem de solver seus débitos de precatórios, pode-se afirmar a inconstitucionalidade de qualquer medida tendente a agravar a já calamitosa situação financeira dos entes públicos, mesmo que aparentemente processual.

Com o escopo de otimizar o sistema de remessa necessária, algumas mudanças poderiam ser efetuadas: a) a extensão das dispensas do $\S 4^{\circ}$ do art. 496 Código de Processo Civil à remessa necessária prevista no $\S 1^{\circ}$ do art. 14 da Lei de Mandado de Segurança (lei n. 12.016/2009); b) uma previsão expressa de remessa necessária ao rito das ACPs, juntamente com a extensão das dispensas jurisprudenciais do $\$ 4^{\circ}$ do art. 496 do Código de Processo Civil; e c) a possibilidade de a lei processual da União prever que cada Estado e 
Rio de Janeiro. Ano 12. Volume 19. Número 3. Setembro a Dezembro de 2018

Município possa estabelecer seu limite econômico para a remessa necessária, conforme os arts. 24, XI, e 30, II, da Constituição Federal.

Caso não se entenda ser o caso de competência do 24, XI, da Carta, poder-se-ia aplicar o parágrafo único do art. 22 da $\mathrm{CF}$ - que permite à União editar lei complementar autorizando Estados e DF a legislarem sobre determinados assuntos de competência legislativa privativa da União (no caso, matéria processual).

Cogita-se, ainda, a possibilidade de a remessa necessária ser incorporada à Constituição Federal por meio de emenda (art. 60 da CF), evitando que maiorias legislativas eventuais tentassem suprimir ou inviabilizar o instituto novamente.

\section{REFERÊNCIAS BIBLIOGRÁFICAS:}

AFONSO, José Roberto R.; BARROS, Gabriel Leal de. A polêmica sobre os precatórios nos orçamentos públicos. Revista FGV/IBRE, São Paulo, out. 2013.

MOREIRA, José Carlos Barbosa. Em defesa da revisão obrigatória das sentenças contrárias à Fazenda Pública. Revista do Instituto de Pesquisas e Estudos, Bauru, n. 44, p. 79-88, set./ dez. 2005. Disponível em: < http://bdjur.stj.jus.br/jspui/handle/2011/18179>. Acesso em: 20 maio 2017.

O futuro da justiça: alguns mitos. Revista de Processo, Rio de Janeiro, v. 102, p. 228-237, abr./jun. 2001. Disponível em: http://www.ablj.org.br/revistas/revista17/revista17\%20\%20JOS\%C3\%89\%20CARLOS\%2 0BARBOSA\%20MOREIRA0001.pdf>. Acesso em: 10 maio 2017.

BARCELLOS, Ana Paula de. Ponderação, racionalidade e atividade jurisdicional. Rio de Janeiro: Renovar, 2005.

BARROSO, Luis Roberto. Curso de Direito Constitucional Contemporâneo. $5^{\text {a }}$ ed. São Paulo: Saraiva, 2015.

BORELLI, Rafael de Souza; SOARES, Marcos Antônio Striquer. Análise crítica do reexame necessário à luz do acesso à justiça e da razoável duração do processo. Revista de Estudos Jurídicos UNESP, Franca, v. 16, n. 24. 2012. Disponível em: $<$ https://ojs.franca.unesp.br/index.php/estudosjuridicosunesp/article/view/601>. Acesso em: 15 maio 2017.

BRASIL. Lei $n^{\circ} 4$ de outubro de 1831. Dá organização ao Tesouro Público Nacional e às Tesourarias das Províncias. Coleção de Leis do Império do Brasil - 1831, p. 103 V. 1. 
Rio de Janeiro. Ano 12. Volume 19. Número 3. Setembro a Dezembro de 2018

Periódico Quadrimestral da Pós-Graduação Stricto Sensu em Direito Processual da UERJ

Patrono: José Carlos Barbosa Moreira (in mem.). ISSN 1982-7636. pp. 138-171

www.redp.uerj.br

BRASIL. Lei $\mathrm{n}^{\mathrm{o}}$ 10.352, de 26 de dezembro de 2001. Altera dispositivos da Lei $\mathrm{n}^{\circ}$ 5.869, de 11 de janeiro de 1973 - Código de Processo Civil, referentes a recursos e ao reexame necessário. Diário Oficial da República Federativa do Brasil, Brasília, 27 dez. 2001.

BRASIL. Lei $\mathrm{n}^{\circ}$ 12.016, de 7 de agosto de 2009. Disciplina o mandado de segurança individual e coletivo e dá outras providências. Diário Oficial da União, Brasília, 10 ago. 2009.

BRASIL. Superior Tribunal de Justiça. Embargos de Divergência no Recurso Especial (EREsp 345752 MG). Embargante: Divema LTDA. Embargado: Município de Carmo do Paraíba. Relator: Min. Teori Albino Zavascki. Brasília, 04 de outubro de 2010.

BRASIL. Supremo Tribunal Federal. AC 3.562/DF - Distrito Federal. Medida Cautelar na Ação Cautelar. Requerente: Estado de Minas Gerais. Requerido: União. Relatora: Min. Carmen Lúcia. Brasília, 28 de fevereiro de 2014.

BRASIL. Supremo Tribunal Federal. ACO 1.062/DF - Distrito Federal. Medida Cautelar na Ação Cível Originária. Requerente: Estado de Minas Gerais. Requerido: União. Relator: Min. Ricardo Lewandowski. Brasília, 13 de agosto de 2014.

BRASIL. Supremo Tribunal Federal. ACO 2.421/MG - Distrito Federal. Medida Cautelar na Ação Cível Originária. Requerente: Estado de Minas Gerais. Requerido: União. Relatora: Min. Cármen Lúcia. Brasília, 18 de janeiro de 2016.

BRASIL. Supremo Tribunal Federal. ACO 830/PR - Distrito Federal. Ação Cível Originária. Requerentes: Estado do Paraná e Paranaprevidência. Requerido: União. Relator: Min. Marco Aurélio. Brasília, 18 de outubro de 2016.

BRASIL. Supremo Tribunal Federal. ADC 4/DF - Distrito Federal. Ação Declaratória de Constitucionalidade. Relator: Min. Sydney Sanches. Relator p/ acórdão: Min. Celso de Mello. Brasília, $1^{\circ}$ de outubro de 2008. Tribunal Pleno. DJe-213 DIVULG 29-10-2014 PUBLIC 30-10-2014 EMENT VOL-02754-01 PP-00001.

BRASIL. Supremo Tribunal Federal. ADI 223 MC/DF - Distrito Federal. Medida cautelar na ação direta de inconstitucionalidade. Relator: Min. Paulo Brossard. Relator p/ acórdão: Min. SEPÚLVEDA PERTENCE. Brasília, 05 de abril de 1990. Tribunal Pleno. DJ 29-061990, PP-06218, EMENT VOL-01587-01 PP-00001.

BRASIL. Supremo Tribunal Federal. ADI 4.467/DF - Distrito Federal. Medida Cautelar na Ação Direta de Inconstitucionalidade. Requerente: Diretório Nacional do Partido dos 
Rio de Janeiro. Ano 12. Volume 19. Número 3. Setembro a Dezembro de 2018 Periódico Quadrimestral da Pós-Graduação Stricto Sensu em Direito Processual da UERJ Patrono: José Carlos Barbosa Moreira (in mem.). ISSN 1982-7636. pp. 138-171 www.redp.uerj.br

Trabalhadores. Requeridos: Presidente da República, Congresso Nacional e Tribunal Superior Eleitoral. Relatora: Min. Ellen Gracie. Brasília, 30 de setembro de 2010.

BRASIL. Supremo Tribunal Federal. ADI 1.158/AM - Distrito Federal. Ação Direta de Inconstitucionalidade. Requerente: Procurador-Geral da República. Relator: Min. Dias Toffoli. Brasília, 20 de agosto de 2014.

CARVAlHO FILHO, José dos Santos. Manual de Direito Administrativo. 30a ed. São Paulo: Atlas, 2016.

COELHO, Inocêncio Mártires. Interpretação constitucional. $3^{\text {a }}$ ed. São Paulo: Saraiva, 2007.

CONSELHO NACIONAL DE JUSTIÇA. Justiça em números 2016: ano-base 2015/Conselho Nacional de Justiça. Disponível em: $<$ http://paineis.cnj.jus.br/QvAJAXZfc/opendoc.htm?document=qvw_1\%2FPainelCNJ.qvw \&host=QVS\%40neodimio03\&anonymous $=$ true \&sheet $=$ shResumoDespFT $>$. Acesso em: 10 maio 2017.

CONSELHO NACIONAL DE JUSTIÇA. Resolução n⿳ 115, de 29 de junho de 2010. Dispõe sobre a Gestão de Precatórios no âmbito do Poder Judiciário. Disponível em: <http://s.conjur.com.br/dl/resolucao-115-cnj.pdf>. Acesso em: 10 de maio 2017.

CUNHA, Guilherme Cardoso Antunes da; REIS, Maurício Martins. Por uma teoria dos precedentes obrigatórios conformada dialeticamente ao controle concreto de constitucionalidade. Revista de Processo, São Paulo, v. 39, n. 235, p. 263-292, set. 2014. CUNHA, Leonardo Carneiro da. A Fazenda Pública em juízo. 11 a edição. Rio de Janeiro: Dialética, 2013.

A Fazenda Pública em juízo. 13ª edição. Rio de Janeiro: Dialética, 2016.

DECOMAIN, Pedro Roberto. O reexame necessário ainda é mesmo necessário? In: Revista Dialética de Direito Processual (RDDP), São Paulo, n. 116, novembro-2012. DIDIER Jr., Fredie. Curso de direito processual civil: introdução ao direito processual civil, parte geral e processo de conhecimento I - 18. ed. - Salvador: Ed. Jus Podivm, 2016.

DONIZETTI, Elpídio. Curso Didático de Direito Processual. 19a . ed. São Paulo: Gen, 2016.

GRAU, Eros Roberto. A emenda constitucional n. 30/00: pagamento de precatórios judiciais. Revista de Direito Administrativo, Rio de Janeiro, 229, jul./set. 2002. 
Rio de Janeiro. Ano 12. Volume 19. Número 3. Setembro a Dezembro de 2018

Disponível

<bibliotecadigital.fgv.br/ojs/index.php/rda/article/download/46430/45162>. Acesso em: 25 fev. 2017.

HESSE, Konrad. A força normativa da Constituição. Porto Alegre: Sérgio Antônio Fabris, 1991.

IBGE - Instituto Brasileiro de Geografia e Estatística. Disponível em: <http://www.ibge.gov.br/home/>. Acesso em: 20 abr. 2017.

Produto Interno Bruto (PIB) real a preços de mercado. Variação percentual em relação ao mesmo período do ano anterior. Atualizado em: 10 de março de 2017. Disponível em: 〈http://www.ipeadata.gov.br/ExibeSerie.aspx?serid=38414〉. Acesso em: 20 abr. 2017.

INSTITUTO DE DIREITO CONTEMPORÂNEO. Disponível em: $<$ http://www.cpcnovo.com.br/wp-content/uploads/2016/06/FPPC-Carta-de-Sa\%CC\%83oPaulo.pdf>. Acesso em 12 abr. 2017.

LENZA, Pedro. Curso de Direito Constitucional. 16. ${ }^{a}$ Ed. São Paulo: Saraiva, 2012. MOTTA, Marianna Martini. Do reexame necessário à luz da constituição federal: tratamento desigual (i)legítimo da fazenda pública. Revista do Instituto do Direito Brasileiro, Lisboa, n. 11, ano 2. 2013. Disponível em: <http://www.idb-fdul.com/ ISSN: 2182-7567>. Acesso em: 15 abr. 2017.

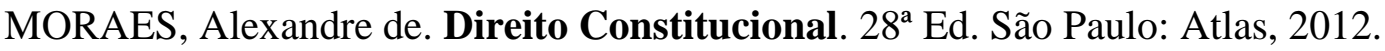

NABAIS, José Casalta. A face oculta dos direitos fundamentais: os deveres e os custos dos direitos. Revista Direito Mackenzie, São Paulo, v. 3, n. 2, 2002. Disponível em: $<$ http://editorarevistas.mackenzie.br/index.php/rmd/article/view/7246>. Acesso em: 15 maio 2017.

OLIVEIRA, Rafael Sérgio Lima de. O reexame necessário à luz da duração razoável do processo. Curitiba: Juruá, 2011.

SCALABRIN, Felipe; SANTANNA, Gustavo. Perfil da remessa necessária no novo código de processo civil. Revista da AJURIS, Porto Alegre, v. 42, n. 137, mar. 2015. Disponível em: <http://www.ajuris.org.br/OJS2/index.php/REVAJURIS/article/view/386>. Acesso em: 17 maio 2017.

THEODORO JUNIOR, Humberto. Novo Código de Processo Civil Anotado. 20ª Ed. Rio de Janeiro: Gen, 2016. 